\title{
Cumhuriyet Türkiye'sine Geçiş Sürecinde Şûrâ-yı Devlet
}

\author{
Zeki Eraslan*
}

\begin{abstract}
$\ddot{O} \mathbf{z}$
Osmanlı modernleşmesinin merkez teşkilatındaki değişim ve dönüşümünün bir parçası olarak yapısal reform sürecinin devamını temin maksadıyla Şûrâ-yı Devletin ihdas edildiği açıktır. Yarım asrı aşkın mücehhez ve mümtaz birikimi ile Cumhuriyet Türkiye'sine tevarüs eden Şûrâ-yı Devlet, 1868-1922 yılları arası dönemde sık sık yapısal değişim geçirmiştir. Günümüzde varlığını Danıştay olarak devam ettiren bu kurumun Cumhuriyet dönemindeki yapısını anlamak için, geçiş süreci olarak adlandırabileceğimiz II. Meşrutiyet ve Millî Mücadele Dönemi'ndeki hukuki gelişmelerin ortaya konulması gerekmektedir. Özellikle Millî Mücadele yıllarında TBMM Hükûmeti, Şûrâ-yı Devletin geleceğini ve varlığını sorgularken, İstanbul'da bu Kurum çalışmalarına devam etmekteydi. Dolayısıyla bu geçiş sürecini İstanbul ve Ankara Hükûmetinin Şûrâ-yı Devlete bakışı üzerinden değerlendirmek gerekmektedir.

Ankara'da Mecliste Şûrâ-yı Devlet üzerinden yapılan tartışmalar ve dönemin basınında yer alan haberler, heterojen bir imparatorluktan homojen üniter Türkiye Cumhuriyeti’ne geçiş sürecinin sancılarını yansıtır niteliktedir. Şûrâ-yı Devlet ile ilgili daha önce tarafimızca yapılan çalışmada Millî Mücadele Dönemi İstanbul ve Anadolu basınıyla TBMM Zabıt Ceridelerinde Şûrâ-yı Devlete nasıl yaklaşıldığına ve bu bağlamda yaşanan tartışmalara yer verilememişti. Bahsi geçen çalışmanın eksikliği arşivde karşılaşılan yeni belgeler, basında yer alan haberler ve bu dönemde hayata geçirilen bazı hukuki düzenlemeler ışı̆̆ında bu çalışmada giderilmeye çalışılmıştır.

Bu çerçevede bu çalışmada II. Meşrutiyet ve Millî Mücadele yıllarında Şûrâ-yı Devletin geçirdiği değişim süreci; yapılan hukuki düzenlemeler, Osmanlı arşiv belgeleri, dönemin basını ve meclis zabıtları üzerinden tahlil edilmeye çalışılacaktır.
\end{abstract}

Anahtar Kelimeler: Şûrâ-yı Devlet, Değişim ve Dönüşüm, Hukuki Düzenlemeler, Zabit Ceridesi, İdari Yargi, Basın, Parlamento

* Dr., Atatürk Kültür, Dil ve Tarih Yüksek Kurumu, Ankara/TÜRKIYE, zeraslan78@hotmail.com ORCID: 0000-0002-4349-2274 DOI: 10.37879/belleten.2021.1025

Makale Gönderim Tarihi: 14.12.2020 - Makale Kabul Tarihi: 05.04.2021 


\title{
Council of State in Transition Process to Republican Turkey
}

\begin{abstract}
It is clear that the Şûrâ-yı Devlet/Council of State was created in order to ensure the continuation of the structural reform process as part of the change and transformation of the central organization of the Ottoman modernization. Şûrâ-yı Devlet/Council of State, which was inherited by the Republic of Turkey with its equipped and distinguished savings of more than a half century, underwent frequent structural changes between 1868-1922. In order to understand the structure of this institution which continues its existence today as Danıstay, revealing the legal developments during the Second Constitutional Era and Turkish National Struggle which could be considered as a transition process is significant.

While the Turkish Grand National Assembly (TBMM) Government was questioning the future and existence of the Council of State, especially during the years of the National Struggle, this institution was continuing its work in Istanbul. Therefore, it is necessary to evaluate this transition process through the approaches of the Istanbul and Ankara governments to Council of State.

The discussions in Ankara at the TBMM Government and news in the press of period reflect the pains of the transition from a heterogeneous empire to a homogeneous unitary state, namely the Republic of Turkey. In my previous study on the Council of State, it could not be possible to examine the issues of how was the approach to the Council of State and related discussions from Istanbul and Anatolian press and the minutes of TBMM during the National Struggle. The lack of the aforementioned study has been tried to be eliminated in this study in the light of new documents encountered in the archive, news in the press and some legal regulations implemented in this period.

In this context, the process of transformation of the Council of State during the II. Constitutional Era and the National Struggle will be analyzed in this article through the legal arrangements made, Ottoman archival documents, press of the period and minutes of the parliament.
\end{abstract}

Keywords: Council of State, Change and Transformation, Legal Regulations, Minutes, Administrative Justice, Press, Parliament

\section{Giriş}

Osmanlı modernleşmesinin merkez teşkilatındaki değişim ve dönüşümünün bir parçası olarak yapısal reform sürecinin devamını temin maksadıyla Şûrâ-yı Devletin ihdas edildiği açıktır. Şûrâ-yı Devlet, Osmanlı Devleti’nde Divân-ı Hümâyûn ile başlayan, Meclis-i Meşveret ile devam eden ve Tanzimat Dönemi’nde çalışma 
usul ve esasları somut olarak tayin edilen meclisli yapı geleneğinin devamıdır. Bu bağlamda parlamento öncesindeki uzun ve derin tecrübeler zincirinin sonucunda karşımıza çıkmaktadır. Kuruluş kanunu olan 1 Nisan 1868 (8 Zilhicce 1284) Nizâmnâme-i Esâsînin 1. maddesi ile Şûrâ-yı Devletin en genel görev tanımı "Mesâlih-i umûmiyye-i mülkiyyenin merkez-i müzâkeresi olmak" şeklinde tayin edilmiştir. Ancak Saray ve Bâb-1 Âlî̀nin Şûrâ-yı Devletten beklentisi bu Kuruma verilen görev, yetki ve sorumluluklardan bahisle bir istişare/danışma işlevinden çok daha fazlasıdır ${ }^{1}$. Bahsi geçen kanunla çizilen çerçeveye göre devlet ve toplumu ilgilendiren mülki iş ve meselelerin görüşüleceği merci olmanın dışında Şûrâ-yı Devletin diğer görev, yetki ve sorumlulukları mevcut kanun ve nizamnamelerin incelenmesi, kendisine Sadaret Makamı tarafindan tevdi edilen kanun lâyihalarının (tasarısı) hazırlaması ve idari denetimi aşan yargısal görevlerdir. Bu görev ve yetkilerle Şûrâ-yı Devlet, kuruluşunda ilham kaynağı olan Fransız Danıştayı (Conseil d'Etat/Konsey Deta) ile oldukça benzerlik taşımaktadır. Uhdesine verilen görev, yetki ve sorumluluklar ile kendinden önceki tecrübeyi de terkip eden Şûrâyı Devlet, hukuki düzenlemelerin de verdiği katkıyla edindiği sistematik çalışma becerisiyle merkezi yönetimde idari rejime geçişin simgesini, dolayısıyla idari yargı sisteminin de temelini oluşturmuştur.

Yarım asrı aşkın mücehhez ve mümtaz birikimi ile Cumhuriyet Türkiye'sine tevarüs eden Şûrâ-yı Devlet, 1868-1922 yılları arası dönemde sık sık yapısal değişim geçirmiştir. Günümüzde varlığını Danıştay olarak devam ettiren Şûrâ-yı Devlet’in Türkiye Cumhuriyeti'ne tevarüs sürecinin anlaşlabilmesi, II. Meşrutiyet ve Millî Mücadele Dönemi'ndeki hukuki düzenlemeleri analiz etmekten geçmektedir. Heterojen bir imparatorluktan üniter Türkiye Cumhuriyeti’ne geçiş sürecinde özellikle Millî Mücadele Dönemi'nde Ankara Hükûmetinin Şûrâ-yı Devlete bakışı günümüzdeki dönüştüğü yapı hakkında da ipuçları vermektedir.

Şûrâ-yı Devlet ile ilgili daha önce tarafimızca yapılan çalışmada² Millî Mücadele Dönemi İstanbul ve Anadolu basınıla TBMM Zabıt Ceridelerinde Şûrâ-yı Devlete nasıl yaklaşıldığına ve bu bağlamda yaşanan tartısmalara yer verilememişti. Bahsi geçen çalş̧manın eksiklïğinin; arşivde karşılaşlan yeni belgeler, basında yer alan ha-

1 Şûrâ-yı Devletin ilk Kanunu olan 1 Nisan 1868 tarihli (8 Zilhicce 1284) Nizâmnâme-i Esâsî’de bu Kurumun görev yetki ve sorumlulukları tayin edilmiştir. BOA, İ.DUİT, 58/51-2. Matbû metin için bk. Düstûr, 1. Tertip, 1. Cilt, Matbaa-i Âmire, 1289, s. 703-706.

2 Hacettepe Üniversitesinde doktora tezi olarak hazırlanan ve yayımlanan bu çalışma için bk. Zeki Eraslan, Şûrâ-yı Devletten Danıştaya: Yapısal ve Fonksiyonel Dönüşüm (1868-1922), Türk Tarih Kurumu Yay., Ankara 2018. 
berler, bu dönemde hayata geçirilen bazı hukuki düzenlemeler ve zabıt cerideleri ışığında makale düzeyindeki bu çalışmayla giderilmesi amaçlanmıştır. Çalışmanın sınırları ve amacı dâhilinde Türkiye tarihinde iki hükûmetli (1920-1922) ve iki anayasalı (1921-1924) kendine özgü bir dönemde İstanbul ve Ankara Hükûmeti'nin Şûrâ-yı Devlete bakışı ve bu bağlamda atılan adımlar ortaya konulmaya çalışılacaktır.

\section{Osmanlı Devleti’nin/İstanbul Hükûmetlerinin Şûrâ-yı Devlete Bakışı}

Şûrâ-yı Devlet, yapılacak reformların yeni merkezi olarak görülüp planlandığından matlâb-1 i'lâya vusul/yüksek hedeflere ulaşmak için devletin tüm üst düzey yöneticilerinin (Bâb-1 Âlî ve Sultan) desteğine eş zamanlı şekilde sahip olmuştur. Sultan Abdülaziz 5 Mart 1868 (11 Zilkade 1284) yllında kurulan Şûrâ-yı Devletin resmi açılışına 10 Mayıs 1868 (17 Muharrem 1285) tarihinde katılarak kendi adına Sadrazam tarafindan okunan Nutk-1 Hümâyûn ${ }^{3}$ ile bu Kuruma yakından ilgi göstermiş ve Şûrâ-yı Devleti desteklemiştir. İlk başkanı (Reîs-i Evveli) Mithat Paşa da bu sürecin sevk ve idaresini elde edilen olumlu atmosferinde de etkisiyle başarıyla yürüttüğünden kuruluşunu takip eden yıllarda Şûrâ-yı Devlet parlak bir dönem yaşamıştır. Ancak Sadrazam Âli Paşa'nın 8 Eylül 1871 tarihinde ölümünden sonra Şûrâ-yı Devlet "hâmî-i hakîkî"sini kaybetmiştir. Aynı tarihte Sadrazam olan Mahmut Nedim Paşa gerek Âli Paşa ve gerekse Mithat Paşa ile arasındaki çekişmeyi menfi tutumu üzerinden en çok Şûrâ-yı Devlet üzerinden yansıtmıştı.

Sadrazam Mahmut Nedim Paşa ile birlikte 1872'de başlayan ve ilga edildiği 1922'ye kadar olan süreçte Şûrâ-yı Devletin etki sahası ve verimliliği siyasi çekişmelere bağlı olarak zaman zaman daralıp zaman zaman da genişlemekle birlikte ilk dört yıl içinde elde ettiği sistemli çalışma başarısına, kendisinden müspet beklenti düzeyine ve devletin tüm üst düzey yöneticilerinin (Bâb-1 Âlî ve Sultan) desteğine eş zamanlı şekilde bir daha asla kavuşamamıştır. Bu durumun en önemli sebeplerinden biri kanaatimizce, daha kuruluşunda bu Kurumun sıkı sıkıya Sadaret Makamına bağlı olarak ihdas edilmesidir. Sürekli yapısal değişikliğge maruz kalan

3 Sultan Abdülâziz'in Şûrâ-yı Devletin resmî açılışında yaptı̆̆ı bu konuşma metninin arşiv belgesi için bk. BOA, HH, 16425; Matbû metin için; Muharrerât-ı Nâdire, Gild-i Sânî, s. 50-53. www.archive.org/stream/ (Collection: Ohio State University Library, publication date 1289/1872); çeviri yazı için bk. Ahmet Lûtfi Efendi, Vak'a-nüvis Ahmet Lûtfi Efendi Tarihi, (Yay. Münir Aktepe) C XII, TTK Yay., Ankara 1989, s. 11-13.

4 Hukuki dayanaklar esas alınarak Şûrâ-yı Devlet hakkında son dönemde yapılmış olan ve Kurumun kuruluş kanunu ile yönetmeliğinin yer aldığı (tam metnin aslı ve çeviri yazısı) bir çalışma için bk. Eraslan, age., s. 279-300. 
Şûrâ-yı Devlet'in durumunu Cevdet Paşa, aynı tarihte kurulan Divân-ı Ahkâm-1 Adliye ile karşılaştırarak şöyle açıklamaktadır ${ }^{5}$.

“...Şûrâ-yı Devlet pek ziyâde âlâyişli olarak teşkîl olundu. Fakîr ise âlâyişe bakmayub esâsının metîn olmasına hasr-ı nazar eyledim. Ahkâm-ı Adliyye dâ’irelerini tedrîc ü tecrübe üzerine teşkîl ve kalemlerini güzelce tanzîm ve mahâkim-i nizâmiyye ilâmlarının usûl-ı sâkk ü sebkini vaz'-1 makbûl ve müstahsen üzerine te'sîs ettim. Binâen-aleyh devâir-i adliyye refte refte tevessü' ve lâyıkıle te'essüs eylemiş olduğuna mebni sonraları Şûrâ-yı Devletin bid'defe'at uğradığı tahavvülât ve inkılâbâttan sâlim kalmıştır..." Cevdet Paşa bu ifadeleri ile Divân-1 Ahkâm-1 Adliyenin sağlam temeller üzerine inşa edildiğine, Şûrâ-yı Devletin ise defalarca yapısal değişikliğe uğradığına dikkat çekmekteydi.

II. Meşrutiyet'e kadar olan kırk yıllık süre zarfında yaklaşık on defa yapısal değişikliğe gidilmiş ancak istenen sonuç bir türlü alınamamıştır. II. Meşrutiyet Dönemi’nde de Şûrâ-yı Devletin yapısıyla ilgili tartışmalara devam edilmiştir ${ }^{6}$. Tartışmalar sonucunda Şûrâ-yı Devletin yapısında ve üye sayısı ile niteliğinde müspet ya da menfi değişiklikler zaman zaman olmakla beraber bu Kurum kamu hizmeti vermeye devam etmiştir. II. Meşrutiyet öncesinde Şûrâ-yı Devlet kadroları gereğinden fazla şişirilmiş olsa da Findleyin isabetle ifade ettiği gibi Kurumun işlevselliğini yitirmemiş olduğu, ürettiği mevzuatın olağanüstü hacminden anlaşılmaktadır ${ }^{7}$. Diğer taraftan II. Meşrutiyet Dönemi’nin Şûrâ-yı Devlet Başkanlarından olan Halil Menteşe ile son Şûrâ-yı Devlet Başkanı Mehmet Tevfik Biren’in Hatıratı İstanbul Hükûmetlerinde Şûrâ-yı Devletin görevlerini yapmaya, sorumluluklarını yerine getirmeye devam ettiğini ortaya koymaktadır. Örneğin Selanik eski valisi Mehmet Tevfik Biren’in anılarından hareketle; Bâb-1 Âlî baskınında olan biteni izlemeye çalışan Şûrâ-yı Devletin Baş Muavinini "Biz işimize gidelim” diyerek kendisinin engellediğini, Şûrâ-yı Devlete giderek çalışmalara devam edildiğini,

5 Ahmet Cevdet Paşa, Tezâkir 40-Tetimme, (Yay.: C. Baysun), 3. baskı, TTK Yay., Ankara 1991, s. 84.

6 Şûrâ-yı Devlet bağlamında II. Meşrutiyet Dönemi yaşanan gelişmeler için arşiv kaynaklarına ilaveten, dönemin canlı tanıkları olan Şûrâ-yı Devlet Başkanlarının Hatıratları sürece ışık tutması açısından oldukça önemlidir. Bu bağlamda; Halil Menteşe, Osmanlı Mebusan Meclisi Reisi Halil Menteşe'nin Anulan, (haz: İsmail Arar), Hürriyet Vakfi Yayınları, İstanbul 1986; Abdurrahman Şeref Efendi Son Vak'anüvis Abdurrahman Şeref Efendi Tarihi, "II. Meşrutiyet Olaylar" (haz. Bayram Kodaman-Mehmet Ali Ünal), TTK Yay., Ankara 1996 ve Mehmet Tevfik Biren'nin II. Abdülhamid, II. Meşrutivet ve Mütareke Devri Anlan 2, (Yayına Hazırlayan: F. Rezan Hürmen), Arma Yay., İstanbul, 1993 adlı eserler dikkat çekicidir.

7 Carter V. Findley, Osmanl İmparatorluğu'nda Bürokratik Reform (çev: Ercan Ertürk), Tarih Vakfi Yurt Yay., İstanbul, 2014, s. 286. 
yine aynı şekilde Bâb-1 Âlî yangınında Şûrâ-yı Devletin civardaki ufak bir binaya nakledildiğini ve çalışmalara orada da devam edildiği ifade edilmektedir ${ }^{8}$. Biren'in anılarında devamla; Şûrâ-yı Devletin kendisine özellikle de hukuki konularda ciddi birikim kazandırdığına, müzakere kabiliyeti olmayan bazı üyeler yer alsa da özellikle Halil Menteşe'nin Şûrâ-yı Devlet Başkanlığı döneminde (1913-1916) yaptı̆̆ı yerinde müdahalelerle sahasında ihtisas sahibi üyelerin Şûrâ-yı Devlette bir araya geldiğine, kendisinin bu Kurumda zevkle çalıştı̆̆ına, Şûrâ-yı Devletin kanun çalışmalarında bir ihtisas heyeti olduğuna, tensikat kanunundan kaynaklı memur mağduriyetlerine bu kanununa müzeyyel bir kanun ile çözüm arandığına, bu bağlamda mağduriyetleri gidermede Şûrâ-yı Devletin önemli bir görev üstlendiğine ve bu esnada kendisinin de Mülkiye Dairesi Reisi olduğuna değinilmektedir9.

\section{Meşrutiyet Dönemi’nde Hukuki Düzenlemeler}

Şûrâ-yı Devletin Cumhuriyet Türkiye'sine geçiş sürecini anlayabilmek için Millî Mücadele Dönemi'nden öncesindeki safhayı ifade eden II. Meşrutiyet Dönemi Şûrâ-yı Devletinin teşkilat yapısı ile görev, yetki ve sorumluluklarını düzenleyen hukuki düzenlemeleri tahlil etmek gerekmektedir. II. Meşrutiyet'in ilanı (23 Temmuz 1908) ile birlikte parlamento yeniden çalısmaya başlamış ve devletin merkez teşkilatında da yeni rejimin ruhuna uygun düzenlemeler yapılmıştır.

Bu doğrultuda 12 Ağustos 1908 (14 Recep 1326) yllında yayımlanan bir İâde-i Seniyye ${ }^{10}$ oldukça önemlidir. Söz konusu irâde, Şûrâ-yı Devletin mevcut yapısıyla üzerine aldığı görevleri yeterince yerine getiremediğine dikkat çekmekte ve üzerinde bazı değişiklikler yapmak suretiyle ilk kurulduğunda hazırlanan nizâmnâmeye dönülmesini ön görmektedir. Daha sonra 3 Eylül 1908 (6 Şaban 1326) tarihli "Şûrâ-yı Devletin Teşkîlât ve Tensîkâtı Hakkında İrâde-i Seniyye" " ile Şûrâ-yı Devletin Mülkiye, Maliye, Tanzimat, Maârif ve Nâfia olmak üzere dört daire ola-

8 Biren, age., s. 69-70.

9 Biren, age., s. 82-85 ve 93-95.

10 "Şûrâ-yı Devletin teşkilât-ı hâzırası mesâlihin hüsn-i cereyânını te'mîne kâfî olmadığından... " şeklinde başlayan İrade-i Seniyye “...Şûrâ-yı Devletin bidâyet teşkilinde mevzû' nizâmnâmenin ba'zı ta dîlâtıyla..." ibaresiyle devam etmekte ve metinde yer alan "...luzûmuna binâ'en evvelce olduğu gibi bir de Ma ârif Dâ'iresi teşkîli muktezâ bulunduğundan..." ifadesiyle ise mezkûr dairenin yeniden kurulmasını teminen Şûrâ-yı Devlet teşkilatında değişikliğe gidilmesine dair öneri getirilmekte olduğu ve bu önerinin uygun bulunup onayladığı anlaşılmaktadır. BOA, İ.DUİT. 58/23-1.

11 Aynı konuya ilişkin Vükelâ Mazbatası için bk. BOA, ŞD, 3197/32'ye; İâde-i Seniyye için ise bk. Düstûr, II. Tertip, I. Cilt, s. 71-72./Damat Paşalara tanınan "a'zâ-yı fahriyye" statüsüne ilk kez bu İâde-i Seniyye'de rastlanmış bulunmaktadır. 
rak yeniden yapılandırılmıştır. Fakat bu durum da kısa sürmüş yeniden düzenleme yapma zorunluluğu doğmuştur. Yapıldığı günün koşullarında kamu personel rejimini derinden etkileyen ve ciddi tartışmalara yol açan 30 Haziran 1909 (17 Haziran 1325) tarihli Tensîkat Kanunun ${ }^{12}$ 1. maddesinin verdiği imkân ile Şûrâ-y1 Devlet Kadroları da gözden geçirilmiş, 14 Ağustos 1909 (1 Ağustos 1325) tarihli Müvâzene-i Umûmîyye Kanûnu ${ }^{13}$ ile Kurumun teşkilat yapısı yeniden düzenlenmişti. Buna göre daire sayısı (Tanzimat), (Mülkiye) ve (Maliye, Nâfia ve Maârif) olmak üzere üçe indirilmiş, Şûrâ-yı Devlet Reisi ilk kez Vükelâ-yı Devlet arasından çıkarılmış ve Şûrâ-yı Devlet, Adliye Nezâretine bağlanmıştır. II. Meşrutiyetin ilanını takip eden yıllarda Şûrâ-yı Devlette önce Mülkiye daha sonra Maliye Dairelerine reislik yapan Mehmet Tevfik Bey (Biren) hatıralarında; bahsi geçen düzenleme çerçevesinde Sadrâzam Kamil Paşa Hükûmetinde Adliye Nazırı olan Damat Arif Hikmet Paşa'nın aynı zamanında Şûrâ-yı Devlet Reisi olarak da tayin edildiğini, bu durumun Fransa'daki usule uygun olduğunu ifade etmiştir ${ }^{14}$. Şûrâ-yı Devlet için bu durum ilk defa söz konusu olmuştur. Bu durum şüphesiz Şûrâ-yı Devlet için devletin merkezi teşkilatında menfi bir gelişmedir. Çünkü Şûrâ-yı Devlet Reisi, Adliye Nâzırı ile eşit statüde Heyet-i Vükelâ/Hükûmet Üyesi olma statüsünü kaybetmiştir. Yaklaşık üç yıl süren bu uygulamadan 21 Ocak 1912 ( 8 Kanûn-1 Sânî 1327) tarihli İâde-i Seniyye ile vazgeçilmiştir ${ }^{15}$. Şûrâ-yı Devletin Adiye Nezâretinden ayrılmasının gerekçesi bu irâdede “...kavânîn-i umûmiye lâyihalarının ekseri burada tanzîm olunmakta olduğu gibi şûrâ-yı mezkûre kavânîn ve nizâmâta tatbîki lâzım gelen mu’âmelâtın merkezî tedkîk ve tatbîki ve mesâ'il-i fevkalâde-i idâriyede kuvve-i

12 Tensîkat Kanununun 1. maddesinde komisyonların teşkil şekline ve görev tanımına yer verilmiştir. Buna göre Meclis-i Âyan'dan bir üyenin başkanlığı, Meclis-i Mebusan'dan bir üyenin ikinci başkanlığı/başkan vekilliği ve ilgili idareden seçilen üç üye ile komisyonlar kurulmuştur. Komisyonların "... devâir-i hukûmetle bi'l-umûm mehâkimde icrâ edilecek teşkilat ve tensikat dolayısıyla..." görev yapacakları hükme bağlanmıştır. Komisyonların çalışma yöntemine ise aynı kanunun 2. maddesinde yer verilmiştir. Toplam 18 maddeden oluşmakla birlikte içerdiği hükümler itibariyle kamu çalışanlarının memuriyet geleceklerine dair radikal kararlara yer veren Tensîkat Kanunu için bk. Düstur, II. Tertip, Cilt 1, s. 326-327; Takvim-i Vekâyi ile neşir ve ilanı 27 Haziran 1325, No: 267. Diğger taraftan Tensîkat Kanunun hazırlanış süreci ve dönemin memurları üzerindeki etkileri konusunda ayrıntılı bir çalışma için bk. Erkan Tural, Son Dönem Osmanh Bürokrasisi: II. Meşrutiyet Dönemi’nde Bürokratlar, Ittihatçllar ve Parlamenterler, TODAİE Yay., Ankara 2009, s. 53-122 ve Biren, age., ss. 83-99. Ayrıca Tensikat Kanunu öncesinde Osmanlı Devleti'nde II. Abdülhamit döneminde de memurların maaş, ödül ve ceza ile yaşam standartlarına ait ciddi problemler ve bu problemlerin 1908'den sonra da devam ettiğine dair ayrıntılı veriler için bk. Carter V. Findley, Ottoman Civil Officialdom, Princeton University Press, New Jersey 1989, s. 293-333.

13 Düstur, II. Tertip, Cilt 1, s. 485.

14 Biren, age., s. 76.

15 BOA, DUIT, 8/51. 
icrâ'iyenin hey'et-i müşâveresi bulunmasıla vezâ'ifini mütenevvie ve cesîm olduğundan.." ibaresiyle ortaya konulmuş olup kanun taslaklarının çoğunlukla Şûrâ-yı Devlette tanzim edildiğine ilaveten hukuki düzenlemelerle ilgili uygulamada karşılaşılan sorunlar için de merkezi idarenin danışma organı olarak, Şûrâ-yı Devletin üstlendiği işlerin yoğunluğu ve çeşitliliğine dikkat çekilmiştir. Diğger taraftan aynı irâdede, Adliye Nezâretinin de işlerinin çokluğu ve çeşitliliğine vurgu yapılmış ve Şûrâ-yı Devlet ile Adliye Nezâretinin aynı kişinin uhdesinde olmasının bazı zorluklara ve gecikmelere yol açtığından bahisle önceki dönemlerdeki gibi Şûrâ-yı Devletin adı geçen bakanlıktan ayrılması "Şûrâ-yı Devlet Riyâsetinin kemâ-fi'ssâbık Adliye ve Mezâhib Nezâretinden tefrîki” ve Heyet-i Vükelâ'ya dâhil edilmesi, riyâsetine ise ehliyetine binaen Said Halim Paşa’nın getirilmesi uygun görülmüştür.

Normlar hiyerarşisi bağlamında daha da önemli bir değissiklik ise Kanûn-ı Esâsî'de olmuştur. Şöyle ki, Kanûn-1 Esâsî’nin 54. maddesinde yer alan "Şûrâ-yı Devlette bi'l-müzâkere tanzim olunacak kavânin lâyihası" ibaresinin 21 Ağustos 1909 (8 Ağustos 1325) anayasa değişikliği ile ortadan kaldırıldığı görülmektedir ${ }^{16}$. Böylece kanun taslaklarının hazırlık sürecinde Şûrâ-yı Devlette müzakere edilmesi anayasal dayanağını yitirmiştir. Şûrâ-yı Devlet için bir diğer değişiklik ise yargısal yetkilerine ilişkin olmuştur. 17 Şubat 1914 (4 Şubat 1329) tarihli Me'mûrîn Muhâkemât-1 Hakkında Kanûn-1 Muvakkat'ın 1. maddesi: "Me'mûrînin vazîfe-i me’mûrîyetlerinden dolayı munbâ'is veya vazîfe-i me'mûrîyetlerinin ifâsı sırasında hâdis olan cürümlerinden dolayı icrâ-yı muhâkemeleri şerâit-i âtîye dâ'iresinde Mehâkim-i Adliyye'ye â’iddir." hükmünü amir olduğundan memur suçları Mehâkim-i Adliyeye tevdi edilmiş ve Şûrâ-yı Devlet nezdinde görev yapan Temyîz, İstinâf ve Bidâyet Mahkemeleri ilga edilmiştir ${ }^{17}$. Böylece memurların memuriyetlerinden kaynaklanan suçların yargılama mercii adli mahkemeler olmuştur.

II. Meşrutiyet Dönemi’nde de Şûrâ-yı Devleti yeniden yapılandırmak ve işlevselliğini artırmak adına devamlı bir arayış söz konusu olmuştur. Sadrazam Said

16 Düstur, II. Tertip, Cilt 1, s. 642-643; Ayrıca Osmanlıdan günümüze tüm anayasa metinleri için bk. A. Şeref Gözübüyük ve Suna Kili, Türk Anayasa Metinleri, Türkiye İş Bankası Yay., Ankara, 1985.

17 Düstur, II. Tertip, Cilt 6, s. 207-211; Bu hususta birkaç noktaya değinmekte fayda görülmektedir: Bu toplam 21 maddeden oluşan bu Kanun, geçici bir süre için hazırlansa da (Kanûn-1 Muvakkat) Türkiye'de tam 85 yıl uygulanmıştır. Memurların memuriyetlerinden kaynaklanan ya da görevi esnasında işledikleri suçların bir ceza yargılamasına esas süreçlerde (ön inceleme/soruşturma gibi) bu kanun hükümlerine uymak zorunluluğu vardır. Neticede, yapılan soruşturmanın sonucuna göre kamu davası açılması istemi ya da men-i muhâkeme kararı verilir. 1914 tarihli bu Kanun, 4/12/1999 tarihli 4483 sayılı "Memurlar ve Diğer Kamu Görevlilerinin Yargılanması Hakkında Kanun” ile yürürlükten kaldırılmıştır. 4483 sayılı Kanun günümüzde de yürürlüktedir. Bk. Düstur, 5. Tertip, Cilt: 39. 
Paşa tarafindan 8 Mayıs 1912 (25 Nisan 1328) tarihinde Şûrâ-yı Devlet Riyâsetine yazılan tezkire oldukça dikkat çekicidir ${ }^{18}$. Zirâ bu tezkirede Şûrâ-yı Devletin ihtisas gerektiren işlerle görevli olduğuna, kanun ve nizamname taslaklarını hazırlarken hukuk kuralları ve genel idari usullere uyduğuna, bu hususların Şûrâ-yı Devletin kuruluş kanunda ön görüldüğüne ve bu ruh ve maksada geri dönülmesi gerektiğine vurgu yapilmıştır.

Şûrâ-yı Devlete işlerlik kazandırma düşüncesi bu Kurumun yeniden teşkilini sağlamaya matuf çabalarla da kendisini göstermektedir. Şöyle ki, 1913 yılında Said Halim Paşa Hükûmetinde Şûrâ-yı Devlet Reisliği yapan Halil Menteşe'nin anılarında; kendisinin başkan olarak görev yaptığı dönemde Şûrâ-yı Devlet kadrolarında düzenlemeler yapıldığı ve hazırlanan kanun lâyihasıyla teşkilat yapısının yeniden gözden geçirilerek Şûrâ-yı Devletin ilham kaynağı olan Fransa'daki işlevine benzer bir statüye kazandırılmak istendiği, bahsi geçen lâyihanın Mecliste görüşülmeye başlandığı ancak 1914 yılında Cihan Harbi’nin başlamasıyla bu çabaların akamete uğradığından bahsedilmiştir ${ }^{19}$. Yine bu anılarda oldukça dikkat çektiği üzere; II. Meşrutiyet öncesi dönem kastedilerek Şûrâ-yı Devlet kararlarının Sadrâzamın tasdiki ile bütün devlet daireleri için hükm-i câri/bağlayıcı olduğuna bu tasdike de "tasdîk-i asâfi" dendiğine, devletin şekli parlamenter Saltanat-1 Meşrûta olunca Sadrâzamın âmiriyet sıfatının kalmadığına ve her nâzırın kendi icraatlarından dolayı Meclis-i Mebusana karşı ayrı ayrı sorumlu olduğundan Şûrâ-yı Devlet kararlarına karşı işine geldikleri gibi davrandıklarına yer verilmiştir ${ }^{20}$. Bu durum Şûrâ-yı Devlet algısının merkezi bürokraside ne şekilde değiştiğini göstermesi bakımından oldukça önemlidir.

Osmanlı Devleti, Şûrâ-yı Devletin teşkilat yapısı ve işlevlerini en son 1918 tarihli bir lâyiha ${ }^{21}$ ile masaya yatırmıştır. Günün koşullarından dolayı yasalaşmasa da

18 BOA, ŞD, 2813/10-2. Tezkire “...Şûrâ-yı Devlet her hükûmette yok ise de mevcud olan devletlerde ihtisâsa tevakkuf eden mesâili hal ve mesâi-i mühimme-i idâriyeyi tedkîk etmek ve kavânin ve nizâmat lâyihalarını kavâid-i hukûkiyeye ve usûl-i umûmiye-i idâreye göre kaleme almak vazifeleriyle meşguldür bizde Şûrâ-yı Devletin nizâmat-ı muhtelifesinin husûsen bidâyet-i teşkilinde yapılan nizâmnâme-i esâsînin ruh ve maksadı dahi buna dalâlet eder..." ibarelerine yer vermiştir.

19 Halil Menteşe, Osmanh Mebusan Meclisi Reisi Halil Menteşe'nin Annlan, (haz. İsmail Arar), Hürriyet Vakfi Yayınları, İstanbul 1986, s. 162-163.

20 Menteşe, age., s. 162.

21 Meclis-i Mebûsan Zabıt Ceridesi, 61. İn'ikat, Celse 1, 3 Mart 1334, s. 63-632. Lâyihanın tam çeviri yazısı için bk. İsmail Hakkı Göreli, Devlet Şûrası (Şûrayı Devlet- Danıştay), Yeni Matbaa, Ankara, 1953, ss. 31-37. 
geride bırakılan 50 yıllık tecrübenin ışı̆̆ında bu dönemde Şûrâ-yn Devlet için en ideal ve gelişmiş kanun teklifi olması bakımından bu lâyiha son derece önemlidir. Şöyle ki, çalışma düzeninin değişmesini hedefleyen bu lâyiha ile Sadaret Makamının havalesi olmaksızın uyuşmazlık konusu hususlarda fertlerin Şûrâ-yı Devlete doğrudan müracaat edebilmelerinin önü açılmak istenmiş, böylece Şûrâ-yı Devlet üzerindeki katı Sadaret Makamı hiyerarşisinin esnetilmesi amaçlanmıştır. Mülkiye ve Maârif, Tanzimat, Maliye ve Nâfia Dairelerine ilaveten bir de Deavî Dairesi ve onun bağlı olduğu Deavî Heyeti kurulmasını önceleyen mezkûr lâyiha ile Şûrâ-yı Devletin yargısal yetki kullanımında da köklü bir değişiklik ön görülmüş̧ür. Kanaatimizce lâyihanın en önemli yönü de burasıdır. Şöyle ki, Şûrâ-yı Devletin yargısal nitelik taşıyan Muhâkemât Dairesi kararları dahi Sadaret Makamına arz edilmeden kendiliğinden yürürlüğe girmemekteydi Bu durum Şûrâ-yı Devletin kurucu hukuki belgelerinde açıkça görülmektedir²2. Üstelik bu noktada Sadareti bağlayan bir norm da söz konusu değildi. Başka bir merciinin onayına sunulmaksızın resen hayata geçemeyen Şûrâ-yı devletin kazaî/yargısal kararları tutuk bir adalet görüntüsü, anlayışı ve sonucuna yol açmaktaydı. İdari yargı kararlarının Sadarete sunulmadan re'sen infâz edilmesiyle tutuk adalete son verilmesi amaçlanmıştı. Bu durum idari yargı mercii olarak Deavî Dairesinin Sadaretten bağımsız olarak yarg1 yetkisi kullanabileceği anlamına gelmekteydi. Lâyihanın bu yönüyle idari yargı düzeninde kuvvetler ayrımını önceleyen oldukça ciddi bir adım olduğu açıktı. Şûrâ-yı Devlet, Fransız Danıştayından (Conseil d'Etat/Konsey Deta ${ }^{23}$ ) ilham alınarak kurulsa da bu yapıyla taşıdığı benzerliklere ilaveten önemli farklılıklar da taşımaktayd ${ }^{24}$. Yapılmak istenen düzenleme ile Fransa'daki tarihsel evrime benzer şekilde 1872 yllından itibaren geçerli olan tutuk adalet (Justice retenue) sistemin-

22 BOA, İ.DUİT, 58/51-2. Matbû metin için bk. Düstûr, 1. Tertip, 1. Cilt,Matbaa-i Âmire, 1289, s. 703-706; BOA, İ. DUIT, 58/48-2. Matbû metin için bk. Düstûr, 1. Tertip, 1. Cilt, Matbaa-i Âmire, 1289, s. 707-718.

23 Bu konuda yapılmış şu çalışmalara bakılabilir. Gaston JEZE, "Collaboration du Conseil d'Etat, et la doktirine dans l'élaboration dudroit administratif français", Livre jubilaire du Conseil d'Etat, 1952; Stanford J. Shaw, "Th e Central Legislative Councils in the Nineteenth Century Ottoman Reform Movement before 1876", International Fournal of Middle East Studies, Cambridge University Press, Vol. 1/No. 1 (Jan., 1970), pp. 73-74. Lamothe, Oliver Dutheillet, "Fransız Danıştay'ı" (Le Conseil d'Etat), (çev:: Hasan Basri Gültekin), Danıştay Dergisi, S. 50-51, Ankara 1983, s. 3-21; Yıldızhan Yayla, "Conseil d'Etat (Yapısı, İslevi ve Yaklaşımı Üstüne)” İdare Hukuku ve İlimleri Dergisi, C 1/S. 1, İstanbul 1980, s. 79-86.

24 Zeki Eraslan, "Şûrâ-yı Devleti Hazırlayan Durum ve Şartlar", 150. Yilında Şûrâ-yı Devletten Damıstaya Uluslararast Sempozyumu, 24-25 Ekim 2018, Danıştay Başkanlığı Yayını No:103, Ankara 2019, s. $38-66$. 
den bağımsız adalet (Justice délégué) sistemine geçişi sağlamanın amaçlandığını söylemek mümkündür.

Yapılan düzenleme çabaları merkezi devlet teşkilatında Şûrâ-yı Devlete yer verme kararlılığını bir kez daha göstermektedir. Şûrâ-yı Devlet, Mütareke Dönemi’nde de çalışmalarına devam etmiş ve İstanbul Hükûmetinin işleyen bir Kurumu olmuştur. Örneğin Şûrâ-yı Devlet Maliye ve Nafia Dairesi, 11 Nisan 1919 (10 Recep 1337) tarihli bir karara imza atmıştır. Karar içeriği incelendiğinde; Divân-1 Muhâsebât tarafindan icra kılınan tedkîkat ve muhâkemât neticesinde Duyûn-ı Umûmiye hesabı denetlenirken hata yaptığı gerekçesi ile adı geçen idarenin muhasebecisine yüz kırk bin yedi yüz doksan kuruşun borç çıkarıldığı, ilgiliden bu meblağın tazminen tahsil edilmeye çalışıldığı, muhasebeci Leon Demircibaşıyan’ın Divân-1 Muhâsebât İlâmını temyizen Şûrâ-yı Devlete götürdüğü, yapılan incelemede adı geçen muhasebeci lehine ilâmın nakz-1 hükmüne/bozulmasına karar verildiği anlaşılmaktadır ${ }^{25}$. Esasen Şûrâ-yı Devletin kurulduğu 1868'den ortadan kaldırıldığı 1922'ye kadar zaman zaman yaşadığı bazı badirelere rağmen görev, yetki ve sorumluluklarını büyük oranda yerine getirebildiği ifade edilebilir.

Millî Mücadele yıllarında Ankara'da Türkiye Büyük Millet Meclisi’nde Şûrâ-yı Devlet'in varlığı tartışmalara konu olurken, İstanbul'da ise Şûrâ-yı Devlet çalışmalarına devam etmekteydi. İstanbul hükûmetinin bu tartışmalara bakışını ve yaklaşımını anlamak amacıyla İstanbul basını incelendiğinde İkdam gazetesinde üç farklı Şûrâ-yı Devlet reisi ile yapılmış beş adet mülakata rastlanmıştır. Bu mülakatların ilki Abdurrahman Şeref Bey ile yapılmıştır² ${ }^{26}$ Bu görüşmede gazete muharririnin sorduğu soruların ülkenin genel gündeminde yer alan iç ve dış politika ile hükûmet çalışmalarında yer alan İstihbarat ve İktisat Komisyonlarına ilişkin olduğu, cevapların da hükûmet üyesi sıfatıyla bu bağlamda verildiği görülmektedir. Bir sonraki mülakat ${ }^{27} 14$ Haziran 1336/1920 tarihindedir. Bu tarihte Şûrâ-yı Devlet Reisi Edhem Bey'dir. Bu mülakatta da Şûrâ-yı Devlet Reisine sorulan soruların Şûrâ-yı Devlet ile ilgili olmadığı görülmektedir. Sorular Paris'te yapılan sulh görüşmelerine katılan Reşid Bey ile Cemil Paşa'nın İstanbul'a dönüşü ve Tedkîkât-1 Sulhiyye Komisyonu ile ilgilidir. Şûrâ-yı Devlet özelinde kendisine bir soru yöneltilmemiştir. İkdam gazetesinin 31 Ekim 1920 (31 Teşrîn-i Evvel 1336) tarihli nüshasında yapılan başka bir mülakata daha rastlanmaktadır. Bu mülakatta muharririn ilk soru-

25 İlk kez bu çalışmada yer verilen karar için bk. BEO, 4568/342528_2

26 İkdam Gazetesi, 15 Teşrîn-i Evvel 1335/15 Ekim 1919, Sayı: 8145, s. 1.

27 İkdam Gazetesi, 14 Haziran 1336/1920, Sayı: 8382, s.1. 
su "Anadolu ile müzâkerât başladı mı? şeklindedir. Sorudan gazetecinin İstanbul Hükûmeti ile Anadolu (TBMM) Hükûmeti arasındaki ilişkilere ilişkin bilgi almaya çalıştı̆̆ı görülse de dönemin Şûrâ-yı Devlet Reisi Mustafa Arif Bey cevaben "Bu husus ile ancak Dâhiliye Nazırı Paşa Hazretleri meşgul olduklarından kendileri mâlûmatdar ve selâhiyatdardırlar. Ben bir şey söyleyemem” demek suretiyle soruyu cevapsız bırakmıştır. Sorulan diğer sorular da Şûrâ-yı Devlet özelinde olmayıp, hükûmetin farklı alanlarda yapacağı yasal düzenlemelere ilişkindir ${ }^{28}$.

Şûrâ-yı Devlet Reisi Mustafa Arif Bey ile yapılan 5 Kasım 1920 (5 Teşrîn-i Sânî 1336) tarihli başka bir mülakatta ise ilk olarak mütareke İstanbul'unda meydana gelen konut stokunun yetersizliğinden meydana gelen ev sahibi-kiracı ilişkilerini yasal zemine oturtmayı hedefleyen Süknâ (Konut/Mesken) Kanunu gündeme gelmiş, mezkûr kanunun önce Şûrâ-yı Devlette görüşüldüğüne sonra da Meclis-i Vükelâ gündemine geldiğine değinilmişti ${ }^{29}$. Bu durum İstanbul Şûrâ-yı Devletinin "kanun lâyihalarının hazırlanmasında ya da hazırlanan lâyihaların gözden geçirilmesindeki” yetkisini bünyesindeki Tanzimat Dairesi tarafindan 1920 yılının Kasım ayında da kullanmaya devam ettiğini göstermesi açısından önemlidir. Diğer taraftan aynı mülakatta ilgi çekici diğer bir konu da Şûrâ-yı Devlet Islahatına da kısmen değinilmesidir. Ancak bu bahis TBMM'de cereyan eden Şûrâ-yı Devlet tartışmalar bağlamında değil, İstanbul Hükûmetince hazırlanan fakat akim kalan lâyihaya yapılan gönderme bağlamında olmuştur ${ }^{30}$.

Son olarak Şûrâ-yı Devlet Reisi Mustafa Arif Bey ile 8 Ağustos 1337/1921 tarihinde üçüncü bir mülakat daha gerçekleştirilmiştir ${ }^{31}$. Bu mülakatın kronolojik olarak diğgerlerinden önemli bir farkı, Şûrâ-yı Devletin memur yargılamalarına ilişkin yetkilerinin TBMM'ye devredildiği 4 Temmuz 1337/1921 tarihli ve 131 sayılı Kanun'dan kısa bir süre sonra yapılmasıdır. Şûrâ-yı Devlet Reisliğine ilaveten Maârif Nazır Vekîli sıfatını da bu tarihte ihraz ettiği görülen Mustafa Arif Bey ile yapılan mülakat içeriği incelendiğinde ilk sorunun yine Şûrâ-yı Devlet ile ilgili değil "Vaz'iyyet-i Umûmiyye-i Siyâsiyye" ile ilgili olduğu görülmektedir". Görüldüğü üzere sorulan soruların hiçbiri Şûrâ-yı Devlet ile alakalı değildir. TBMM'de kabul edilen bahsi geçen düzenleme gündeme dahi gelmemiştir. Bu durumu Şûrâ-

\footnotetext{
28 İkdam, 31 Teşrîn-i Evvel 1336/31 Ekim 1920, Sayı: 8494, s.1.

29 İkdam, 5 Teşrîn-i Sânî, 1336/5 Kasım 1920, Sayı: 8499, s. 2.

30 İkdam, 5 Teşrîn-i Sânî, 1336/5 Kasım 1920, Sayı: 8499, s. 2.

31 Ikdam, 8 Ağustos 1337/1921, Sayı: 8765, s. 1.

32 İkdam, 8 Ağustos 1337/1921, Sayı: 8765, s. 1.
} 
yı Devlete karşı ilgisizlik olarak görmek yanlış olur. İstanbul merkezli de olsa yer verdiği "Anadolu Haberleri” başlığı altında Millî Mücadeleyi desteklediği görülen İdam gazetesi ve yazarlarının önceliği günün koşullarına uygundur. Mütareke koşullarında ülkenin beka sorunu yaşadığı bir dönemde gazetecilerin bu meyanda soru sormaları pek tabidir. Verilen cevaplar da gündem ve önceliklere uygun olarak bir hükûmet üyesinin cevaplarıdır.

İstanbul Hükûmeti Şûrâ-yı Devletin etkin bir şekilde çalışmasını istemektedir. Zira dönemin basını incelendiğinde Şûrâ-yı Devlet’in toplandığına dair haberler yer almaktadır. Örneğin 16 Mayıs 1337/1921 tarihli habere göre bu tarihte Şûrâyı Devletin Heyet-i Umûmiyesinin gündeminde, bazı şirketlerin Teşvîk-i Sanayi Kanunundan yararlanıp yararlanamayacağı, mahkemelerin işgal ettiği binaların Mesken Kararnamesine tabi olup olmadığı hususlarının bulunduğu ve karar almak için toplanıldığı ifade edilmektedir ${ }^{33}$. Haberin dikkat çekici yönü, Şûrâ-yı Devletin kurulduğu günden itibaren kanun ve kararnameleri tefsir etme ve şirketlere verilecek imtiyazlara ilişkin görüş verme yetkisini uhdesinde koruyabilmiş olduğunu göstermesidir. Bu çerçevede Şûrâ-yı Devletin Genel Kurulu mahiyetinde görev yapan Heyet-i Umûmiyenin aktif olarak görev yaptığını görmekteyiz. Başka bir haberde de İstanbul Belediyesi Eski Başkanı Selim Paşa ile yardımcısı Mehmet Ali Bey'in, görevleri sırasında yolsuzluk yaptıkları gerekçesi ile Ağustos 1922'de Şûrâ-yı Devlette yargılanmaya başlandığı bildirilmekteydi ${ }^{34}$.

Osmanlı Devleti'nin Şûrâ-yı Devleti geliştirerek muhafaza etme konusunda ısrarı son olarak 26 Kanûn-ı Evvel 1337/26 Aralık 1921 tarihinde çıkan Dâhili Haberler başlı̆ğının altında "Yeni Şûrâ-yı Devlet Teşkilatı" alt başlıklı haberde ${ }^{35}$ kendini göstermektedir. Habere bakıldığında Şûrâ-yı Devlet Reisi Tevfik Beyin ${ }^{36}$ Başkanlığında, Şûrâ-yı Devlet Daire Başkanları ile Başkâtibin katılımıyla Şûrâ-yı Devletin yapısını tetkik etmek için bir komisyon kurulduğuna ve bu komisyonun çalışmasını tamamladığına yer verilmektedir. Komisyonun hazırladığı lâyihayı Meclis-i Vükelâ'ya takdim etmeden önce gözden geçirmek için son bir kez daha toplanacağına yer verilen haberde, lâyihanın içeriğine de yer verilmiştir. Şöyle ki,

33 İkdam, 16 Mayıs 1337/1921, Sayı: 8683, s. 2.

34 Peyâm- Sabah ve Vakit gazetelerinden aktaran, Zeki Saruhan, Kurtuluş Savaşı Günlüğü, IV, TTK Basımevi, Ankara 1996, s. 615.

35 İkdam, 26 Kanûn-1 Evvel 1337/26 Aralık 1921, Sayı: 8901, s.2.

36 Tevfik Bey, Osmanlı Şûrâ-yı Devletinin son başkanıdır. Görev süresi 19 Ağustos 1922-4 Kasım 1922 arasıdır. Kurulduğu 1868'den 1922'ye kadar görev yapan Şûrâ-yı Devlet Reislerinin adları ve görev sürelerinin yer aldığı tablo ve istatistiki bir şema için bk. Eraslan, age., 161-165. 
Şûrâ-yı Devlette mevcut bulunan Maliye ve Nâfia, Mülkiye ve Maârif ile Tanzimat Dairelerine ilaveten De'âvî Dairesinin kurulması teklif edilmektedir ${ }^{37}$. Esasen bu dairenin kurulması 1918 yılında hazırlanan ancak yasalaşamayan Şûrâ-yı Devlet Lâyihasında da söz konusudur. 1918 yılında yasalaşamayan lâyiha raftan tekrar indirilmiştir. Ancak bu son teklifin akibeti de önceki ile aynı olmuştur. Şûrâyı Devlette De’âvî Dairesinin kurulması ise Cumhuriyet Türkiye'sinin başardığı çok önemli bir adım olmuştur. Bu doğrultuda 1918 tarihli Şûrâ-yı Devlet Lâyihasının idari yargı düzeninde getirmek istediği radikal değişiklikler Cumhuriyet Türkiye'sinin 1925 tarihli ve 669 sayılı ilk Şûrâ-yı Devlet Kanunu ile mümkün olabilmiştir ${ }^{38}$.

\section{Millî Mücadele Dönemi'nde Ankara Hükûmetinin Şûrâ-yı Devlete Bakışı}

I. Dünya Savaşının kaybeden devletleri arasında yer alan Osmanlı Devleti, işgallere zemin hazırlayacak olan Mondros Ateşkes Antlaşması'nı 30 Ekim 1918'de itilaf devletleri ile imzalamıştı. Başlayan işgaller karşısında Mondoros Ateşkes Antlaşması'na bir tepki olarak 28 Ocak 1920 yılında Son Osmanlı Mebusan Meclisi'nde Misâk-1 Millî̉ ${ }^{39}$ kabul edilmişti.

Misâk-1 Millî Kararları sonrasında İngilizlerin öncülüğünde İtilaf Devletlerinin muhtelif baskıları başlamış ve bu baskılar 16 Mart 1920 yılında İstanbul'un işgal edilmesi ile sonuçlanmıştı. Mebusan Meclisi de 11 Nisan 1920 tarihinde Padişah tarafindan feshedilmişti. Durum böyle olsa da ülke yönetiminde parlamentonun önemi ve vazgeçilmezliği başta Mustafa Kemal olmak üzere Yeni Türkiye Devletinin inşa edicileri tarafindan öncelikli olarak takdir edildiğinden Meclisin yeniden ve Ankara'da açılmasına karar verilmiş ve bu bağlamda 23 Nisan 1920'de Türkiye Büyük Millet Meclisi açılmıştır. Bu tarihten itibaren Osmanlı Devleti resmi varlığını bir süre daha devam ettirse de Yeni Türk Devletinin ihtiyaç duyacağı yasal düzenlemelerin kaynağı artık TBMM'dir. Nitekim çalışmada daha sonra da atıf yapılacak olan Saltanatı ortadan kaldıran TBMM'nin 1 Kasım 1922 tarihli

37 İkdam, 26 Kanûn-1 Evvel 1337/26 Aralık 1921, Sayı: 8901, s.2.

381918 tarihli Osmanlı Dönemi Şûrâ-yı Devlet Lâyihası ile Türkiye Cumhuriyeti’nin ilk Şûrâ-yı Devlet Kanunu arasındaki benzerlikler ve farklılıkları konu edinen mukayeseli müstakil bir makale çalışmasına ihtiyaç olduğu tarafimızca değerlendirilmektedir.

39 Fahir Armaoğlu, "Tarihi Perspektif İçinde Misakımillì’nin Değerlendirilmesi”, Misakı Millı ve Türk Dış Politikasında Musul, Atatürk Araştırma Merkezi, Ankara 2012, s. 5. Konunun değişik cepheleri için aynı kitapta yer alan diğer makalelere bakılabilir. 
308 nolu kararında yer alan “... Türkiye halkı hâkimiyet-i şahsiyeye müstenit olan İstanbul'daki şekl-i Hükûmeti 16 Mart 1336/1920'den itibaren ebediyen tarihe müntakil addeylemiştir.” ibareler TBMM Hükûmetinin gücün tek meşru kaynağı olarak görüldüğünü ortaya koymaktadır ${ }^{40}$.

Şûrâ-yı Devletin geleceğine karar verecek merci de 23 Nisan 1920'den itibaren TBMM olacaktır. TBMM öncelikli iş olarak 7 Haziran 1336/1920 yılında "16 Mart 1336/1920 Tarihinden İtibaren İstanbul Hükûmetince Akdedilen Bi’l-cümle Mukavelât, Uhûdât ve Sâirenin Keenlemyekûn Addî Hakkında Kanunu ${ }^{41}$ " kabul etmiş ve ülkenin geleceğinde belirleyici olacağını ortaya koymuştu. Kanunun kendine milat kabul ettiği tarih İstanbul'un işgal edildiği tarihtir. Bir gönderme söz konusudur. İşal altında bulunan bir şehirde yer alan parlamento ya da hükûmetin hür bir şekilde karar alamayacağına bu türden alınan kararların yok hükmünde sayılacağı yeni kanun koyucu (TBMM) tarafindan ilan edilmiştir. Mustafa Kemal Paşa'nın yönettiği yedinci celse görüşmelerinde bu kanun maddesi kabul edildiğinde hemen ardından adı geçen kanun aleyhine hareket edenler için Burdur Milletvekili İsmail Suphi Bey tarafindan “....milletçe malî zarar ve ziyanlarından dolayı tazmine tâbi tutulurlar" şeklindeki verilen takrîr/önerge ise kabul görmemiştir. ${ }^{42}$.

Bu kanun, Şûrâ-yı Devlet açısından ise şu anlama gelmekte idi. Kurulduğu 1868 yllından itibaren hükûmetçe imzalanan her türlü mukavele ve imtiyaz sözleşmeleri için bağlayıcı olmasa da Şûrâ-yı Devletten görüş alınması bu Kurumun Kanunu vasfindaki 1Nisan 1868 (8 Zilhicce 1284) tarihli Nizâmnâme Esâsînin 3. maddesi ${ }^{43}$ ile yönetmeliği vasfindaki Nizâmnâme-i Dâhilîsinin 22. maddesi ${ }^{44}$ doğrultusunda hukuken gerekli idi. Ancak 7 Haziran 1336/1920 tarihli Kanun kabul edildiği tarihten itibaren ülkenin içinden geçtiği olağanüstü koşullarda yaklaşık üç ay geriye doğru yürütülerek İstanbul'un işgal edildiği 16 Mart 1920 başlangıç kabul edildiğinden "İstanbul Hükûmetinin baskı altında olduğundan bahisle" imza altına aldığı mukavele ve anlaşmalar geçersiz sayılmıştır. Yani Şûrâ-yı Devletin 16 Mart 1920'den itibaren bu anlamda kullanabileceği istişari yetkinin uygulamada

40 TBMM Kararı No: 308 (1 Teşrîn-i Sânî, 1338), www.tbmm.gov.tr/kutuphane/tutanak_sorgu. html(Erişim tarihi 14.01.2020)

41 Bu Kanunun Ceride-i Resmîye ile Neşir ve İlânı: 14 Şubat 1337/ 1921, No:2.

42 TBMM Zabıt Ceridesi, İçtimâ: 25, Celse: 7, (7.6.1336), s. 145.

43 BOA, İ.DUİT, 58/51-2. Matbû metin için bk. Düstûr, 1. Tertip, 1. Cilt, Matbaa-i Âmire, 1289, s. 703-706.

44 BOA, İ. DUİT, 58/48-2. Matbû metin için bk. Düstûr, 1. Tertip, 1. Cilt, Matbaa-i Âmire, 1289, s. 707-718. 
TBMM Hükûmeti için bir anlamı olmayacaktır. Kaldı ki, ülkenin içinde bulunduğu koşullar, diğer kurumlar açısından olduğu gibi Şûrâ-yı Devlet için de son derece elverişsizdi.

TBMM ise yaptı̆̆ı yasal düzenlemelerde Anadolu'da hâkimiyetini pekiştirmek istemekteydi. Ancak TBMM, adli ve idari yargmnn temyiz mercilerinin Anadolu'da inşası noktasında seçici davranmaktaydı. Şöyle ki, tutuk adalet mahiyetini haiz olsa da idari yargının istinaf ve temyiz mercii olan Şûrâ-yı Devlet ile Mahkeme-i Temyize yaklaşım biçimi farklı idi. Şûrâ-yı Devlet konusundaki zaman zaman sessizlik, akışına bırakma, tartışılsa da uzun bir süre sonuca bağlayamama, ileride değinileceği üzere bazı mebusların retçi tutumu ve netice de Millî Mücadele Dönemi’nde ihdas edilmeme süreç ve sonucu adli yargı temyiz organı için aynı şekilde tezahür etmemiştir. TBMM'nin açılısını takiben daha iki ay dolmadan hızlıca gündeme alınarak hazırlanan ve yürürlüğe giren 7 Haziran 1336/1920 tarihli ve 4 sayılı Kanun ${ }^{45}$ ile Sivas'ta "Heyet-i Temyiz" kurulmuştur" ${ }^{46}$. Toplam 8 maddeden oluşan bu kanunun 1. maddesi ile şeriye, hukuk, ceza ve istida olmak üzere dört daireden mürekkep bir muvakkat temyiz heyeti kurulmuştur. Kanaatimizce bu kanunun amacı Anadolu'daki ilk derece adli yargı mercileri ile İstanbul Mahkeme-i Temyîzi arasındaki bağı koparmak ve bu suretle TBMM'nin otoritesini kuvvetlendirmektir.

\section{Yılı Bütçe Görüşmelerinde TBMM'de Şûrâ-yı Devlet Tartışmaları}

1336/1920 yılı Bütçe Görüşmelerinde Şûrâ-yı Devlete de yer verilmesi Yeni Türk Devletini kurma yolunda olan kadroların bu Kuruma devletin merkezi teşkilatında yer vermeye kararlı olduklarını gösteriyor ${ }^{47}$. Ancak bu konuda hemfikir olma durumu söz konusu değildi.

Bahsi geçen bütçe görüşmelerine esas Muvâzene-i Umûmiye Lâyihasının görüşülmeye başlandığında reis olarak oturumu yöneten Hasan Fehmi Bey: "Bütçe müzâkeresine geçiyoruz. Şûrâ-yı Devlet bütçesini müzâkere edeceğiz" dediği anda Meclisten "Şûrâ-yı Devlet yok sesleri” yükselmiştiti ${ }^{48}$ Meclis gündemine ge-

45 Cerîde-i Resmiye ile Neşir ve ilanı, 7 Şubat 1337/1921, No: 1

46 Rıdvan Akın, TBMM Devleti (1920-1923), İletişim Yay., İstanbul, 2001, s. 152 ve 154. Diğer taraftan bu konuda ayrıntılı bilgi için bk. Fatmagül Demirel, https://ataturkansiklopedisi.gov.tr/bilgi/ Adliye_Vekâleti (erişim tarihi 15/12/2020)

47 TBMM Zabut Ceridesi, İçtimâ: 158, Celse 1, (27.2.1337), s. 467-468.

48 TBMM Zabıt Ceridesi,, İçtimâ: 158, Celse 1, (27.2.1337), s. 467. 
len Şûrâ-yı Devlet bütçesi ${ }^{49}$ toplamda 3 fasıl/bölüm ve 17 kalemden oluşmaktaydı. Tasarı haliyle Bütçe Kanunu, Şûrâ-yı Devlete aşağıdaki tabloda gösterildiği şekilde yer vermekteydi:

\section{Birinci Fasıl/Bölüm}

Nev'-i Muhassasat/Tahsîs Türü Hükûmetçe Teklif olunan Encümence kabul edilen Maaşa

\begin{tabular}{|c|l|c|c|}
\hline 1 & Şûrâ-yı Devlet Riyâseti & 0 & 900 \\
\hline 2 & Reîs-i Sânîler (Daire Başkanları) & 0 & 1350 \\
\hline 3 & Tanzimat Dairesi & 0 & 1680 \\
\hline 4 & Mülkiye ve Maârif Dairesi & 0 & 1680 \\
\hline 5 & Maliye ve Nâfia dairesi & 0 & 1680 \\
\hline 6 & Heyet-i Umûmiye Kalemi & 0 & 270 \\
\hline 7 & Mazbata Kalemi & 0 & 480 \\
\hline 8 & Sicil Kalemi & 0 & 150 \\
\hline 9 & Evrak ve Dosya Kalemi & 0 & 270 \\
\hline 10 & Müstahdemin-i Müteferrika (Hizmetli masrafları-Hesapdışı) & 0 & 72 \\
\hline
\end{tabular}

Bölüm Toplamı/Faslın Yekûnu: 8. 532 (Sekiz Bin Beş Yüz Otuz İki)

\section{İkinci Fasıl/Bölüm}

Nev'-i Muhassasat/Tahsîs Türü Hükûmetçe Teklif olunan Encümence kabul edilen Mesârif

\begin{tabular}{|c|l|c|c|}
\hline 1 & Kırtasiye & 0 & 200 \\
\hline 2 & Evrâk-1 Matbûa & 0 & 200 \\
\hline 3 & Mefrûşat & 0 & 500 \\
\hline 4 & Meremmet (Tamirat/Tadilat) & 0 & 0 \\
\hline 5 & Evrak Dosyası & 0 & 100 \\
\hline 6 & Kütüphane ve Kitap & 0 & 200 \\
\hline
\end{tabular}

Bölüm Toplamı/Faslın yekûnu: 1.200 (Bin iki yüz lira)

49 Ayni yer, s. 467-468. 


\section{Üçüncü Fasıl/Bölüm}

Hükûmetçe Teklif olunan Encümence kabul edilen Nev'-i Muhassasat/Tahsîs Türü

\begin{tabular}{|l|l|c|c|}
\hline 1 & $\begin{array}{l}\text { Memûrin ve Müstahdeminin Tahsîsât-1 Fevkalâde-i Şehriyesi } \\
\text { (Memur ve hizmetlilerin aylık öngörülemeyen ödeneği) }\end{array}$ & 0 & 12512 \\
\hline
\end{tabular}

\section{Üç Fasıl ve 17 Kalem Giderin Genel Toplamı ( Yekûn-u Umûmi):}

22. 244 (Yirmi iki bin iki yüz kırk dört lira).

(Tablodan da anlaşıldığı üzere Şûrâ-yı Devlete aktarılması planlanan ödenek 22.244 (Yirmi iki bin iki yüz kırk dört liradır.)

1920 Yılı Muvâzene-i Umûmiye Kanunu ${ }^{50} 28$ Şubat 1337/1921 yılında 25 maddeden ibaret olarak kesinleştiğinde TBMM'nin ilk Bütçe Kanununun büyüklüğü Kanuna ekli A Cetvelinde gösterilmiş olup toplam 63.018.354 (Altmış üç milyon on sekiz bin üç yüz elli dört) lira idi. Ancak mezkûr kanunun şaşırtıcı yönü Şûrâ-yı Devlet hususunda idi. Bütçe Kanunu Lâyihasında (Tasarısında) Şûrâ-yı Devlete 22.244 (Yirmi iki bin iki yüz kırk dört) lira gibi oldukça mütevazı bir ödenek öngörülmüşken mali yıl öncesi kesinleşen hesap kanununda hiç ödenek ayrılmamıştı. Oysaki, II. Meşrutiyet Dönemi’nde genel bütçe ilkelerini sarahaten ortaya koyan, vergi toplama ve harcama usul ve esaslarını belirleyen 14 Ağustos 1909 (1 Ağustos 1325) tarihli Muvâzene-i Umûmîyye Kanûnu ile Şûrâ-yı Devlete 5.152. 227 (beş milyon yüz elli iki bin iki yüz yirmi yedi) kuruş ödenek ayrıldığg1 ${ }^{51}$ dikkate alındığında bu Kurumun Yeni Türk Devletinin bütçe politikasında kaybettiği itibar daha iyi anlaşlacaktır.

Millet iradesinin ve Yeni Türk Devletinin tecessüm ettiği TBMM, mütareke sonrası dönemde ülkenin var olma mücadelesi verdiği olağanüstü koşullarda ulusal ve uluslararası düzeyde ülkeyi sevk ve idare etmeye başlamıştı. Hâl böyleyken Bütçe Kanununun önceliklerinin siyasi/askeri alanda olması gayet anlaşılır bir durumdu. Ancak durum böyle olsa da çalışmanın ilerleyen kısmında yer verileceği üzere Şûrâ-yı Devlete karşı Mecliste ciddi muhalefet söz konusuydu. Şûrâ-yı Devlet

5028 Şubat 1337/ 1921 tarihli 103 no.lu Kanun. (Cerîde-i Resmîye ile Neşir ve İlanı: 25 Nisan 1337, No:12); Diğer taraftan bu kanunla ilgili yapılan bir çalışma için bk. Rıdvan Akın, "TBMM’nin İlk Bütçe Yasass: 1336 Muvazene-i Umumiye Kanunu", İstanbul Üniversitesi Atatürk İlkeleri ve İnkalap Tarihi Enstituisü Dergisi, S. 2, (2002), s. 1-40.

51 Diustur, II. Tertip, Cilt: 1, s. 444 ve 485-486. Şûrâ-yı Devlete ayrılan ödenek, toplam 37 maddeden oluşan bu kanunun ekinde yer alan 1 numaralı cetvel ile gösterilmiştir. Cetvel incelendiğinde Şûrâ-yı Devlet hizmet birimleri ve diğer giderlerin ayrıntılı bir şekilde ortaya konulduğu görülmektedir. 
aleyhine oluşan menfî tutum bütçe ayrılmamasında son derece etkiliydi. Örneğin aynı bütçede bugünkü Sayıştay olan Divân-ı Muhâsebat, Şûrâ-yı Devlet gibi yok sayılmamış ve Divân-1 Muhâsebata 26.696 (Yirmi altı bin altı yüz doksan altı) lira ödenek ayrılmıştı.

TBMM açıldığında Osmanlı Devleti resmen yıkılmamış olsa da ülke yönetiminde tek söz sahibi TBMM Hükûmeti olmaya çalışmıştır. Nitekim Mustafa Kemal Paşa, İstanbul'a Tevfik Paşa'nın (Sadrazam) dikkatine çektiği telgrafta: "İrâde-i Milliyeye müsteniden Türkiye'nin mukadderâtına vâzı-ul yed (el koyan) olan yegâne meşrû ve müstakil kuvve-i hâkime Ankara'da müstemirren (devamlı) mün'akid (toplanan) Türkiye Büyük Millet Meclisidir.” demek suretiyle bu anlayışı yansıtmaktadır ${ }^{52}$. Bu yaklaşım pek doğal olarak kendini mali yönetim alanında da göstermiştir. Bu bağlamda TBMM tarafindan, 1336/1920 Muvâzene-i Umûmiye Kanunu ile ülkenin tüm vergi gelirine talip olmuş olunmakla birlikte Osmanlının İstanbul merkezli Kurumları ile borçlarına (Örneğin Duyûn-u Umûmiye için 7. 680. 696/yedi milyon altı yüz seksen bin altı yüz doksan altı lira ödenek ayrılmıştı) da sahip çıkılmıştır. Mezkûr kanunun 8. maddesi kanunun izin vermediği hiçbir mercinin vergi koyamayacağını, tahsil edemeyeceğini, bu bağlamda hazineye ait paraları toplayamayacağını aksi takdirde aykırı hareket edenlerin "Hıyânet-i Vataniye Kanunu mucibince tecziye edileceklerini” karara bağlamıştı. ${ }^{53}$.

\section{Millî Mücadele Dönemi Anadolu Basınında Şûrâ-yı Devlet}

Ankara Hükümetinin Şûrâ-yı Devlete bakışını ve meclisteki tartışmaların Anadolu basınına nasıl yansıdığını anlamamıza imkân sağlayacak iki önemli gazete bulunmaktadır. Bunlardan ilki, 4 Eylül 1919 Sivas Kongresi'nin ardından Kongre Heyetinin aldığı karar ile 14 Eylül 1919'da ilk sayısı neşredilen İâde-i Milliye gazetesi $^{54}$, ikincisi ise 10 Ocak 1920'den itibaren yayın hayatına başlayan Hâkimiyet-i Milliye $^{55}$ gazetesidir. Ancak hemen belirtmekte fayda var ki, bahsi geçen gazetelerde 1919-1922 arası dönemde Şûrâ-yı Devlet için ciddi veriye rastlanılamamıştır.

52 TBMMZC, İçtima: 139, Celse 1 (29.1.1337), s. 411.

53 TBMM Zabut Ceridesi, (İçtima:158, Celse 2, 27.2.1337)/ 28 Şubat 1337 tarihli 103 no.lu Kanun. (Cerîde-i Resmîye ile Neşir ve İlanı: 25 Nisan 1337/1921, No:12)

54 Irâde-i Milliye Gazetesi, tıpkıbasım ve yeni harflerle 2014 yılında (4. baskısı), Sivas Belediyesi tarafindan yayımlanmıştır.

55 Hâkimiyet-i Milliye Gazetesi 10 Ocak 1920'den itibaren yayın hayatına başlamış ve daha çok Millî Mücadele sürecindeki siyasi, askeri ve diplomatik gelişmelere yer vermiştir. Gazete, çalışmanın sınırları dâhilinde alınan dönem için Şûrâ-yı Devleti doğrudan konu eden yazılara pek yer vermese de İstanbul'daki gelişmeleri yakından takip etmiştir. Bu kanaate, gazetenin 1336/1920 ve 1337/1921 yılı nüshalarının incelenmesi sonucu ulaşılmıştır. 
Kanaatimizce bunun en önemli sebebi, Millî Mücadelenin sevk ve idaresinin yapıldığı Anadolu'da, ülkenin içinden geçtiği ve var oluş mücadelesi verdiği koşullara basının da eş zamanlı olarak öncelik vermesidir. Basında siyasi ve askeri gelişmelere ilgi düzeyi oldukça yüksektir. Bu durum gayet doğaldır. Osmanlı Devleti tarihinde en sık hükûmet değişiklikleri 1918-1922 arasında söz konusu olmuştur. Bu durum tam bir siyasal istikrarsızlık göstergesidir. Örneğin 11 Kasım 1918 ile 1 Ekim 1919 arasında bir yılda tam altı defa hükûmet değişikliği söz konusu olmuştur $^{56}$. Bahsi geçen gazeteler ise İstanbul'daki faaliyetlerine devam etmekte olan Şûrâ-yı Devlet ile ilgili haberlere kısmen de olsa yer vermişlerdir. Örneğin İâde-i Milliye gazetesi tehcir olup eski yurtlarına/meskenlerine dönen memleketin beğenisini kazanmış makbul kişilerin vergi ve yükümlülüklerden istisna tutulacaklarını Şûrâ-yı Devletin karara bağladığını haber sayfalarına taşımıştır ${ }^{57}$.

Gazete İstanbul'daki hükûmet değişikliklerini yakından takip etmiştir. Bu bağlamda Şûrâ-yı Devlet Reisliğine Abdurrahman Şeref Bey’in getirildiğini ${ }^{58}$, başka bir hükûmet değişikliğinde ise Şûrâ-yı Devletin başına Cemil Molla Bey’in atandığ1 haber verilmektedir ${ }^{59}$. Yine aynı gazete, Sivas Mebusu Bacanakzade Ziya'nın, meclis üyeliği ile ilgili bir meselede kanunla kendisine verilen yetkinin tefsir/yorum olduğu halde fesih kararı almak suretiyle yetkisini aştığından bahisle Şûrâ-yı Devleti eleştiren bir yazısına da yer vermiştir ${ }^{60}$.

Hâkimiyet-i Milli gazetesi de çalışmanın konu edindiği dönem için dikkate alındığında tıpkı Irâde-i Milliye gazetesi gibi spesifik olarak Şûrâ-yı Devleti konu edinen ayrıntılı bir habere yer vermemiştir. Bu durum yukarıda da bahsedildiği üzere öncelikler ile ilgilidir. Ancak bu gazete de başta hükûmet değişiklikleri olmak üzere İstanbul'daki gelişmelere yakın ilgi duymuştur. Gazetenin 25 Ekim 1920 (25 Teş-

56 Açılamalı Yönetim Zaman Dizini (1919-1928), G 1, (Editör Nuray E. Keskin), Ankara Üniversitesi Siyasal Bilgiler Fakültesi Yayını, No: 604, Ankara, 2012, s. 18-23; Ayrıca İstanbul Hükûmetleri hakkında ayrıntılı bilgi için bk. Sina Akşin, Istanbul Hükümetleri ve Milli Mücadele, C I-II, Türkiye Işs Bankası Yayınları, Ankara, 1998.

57 Irâde-i Milliye, 22 Kanun-1 Evvel 1335, Numara:17, sayfa 4. "Tehcîr olunan veya memâlîk-i müstahsen ahâlisinden olub da me’vâ-yı kadîmelerine avdet edenlerin rüsûm, tekâlif ve temettü vergisinden istinaları lüzumu Şûrâ-yı Devletçe takarrür eylemiştir." Sivas Belediyesi tarafindan yaptırılan çeviri yazıda "müstahsen" kelimesinin "müstahlasîn” şeklinde (s.149) çevrildiği görülmüş olup gerekli düzeltme yapılmıştır.

58 Irâde-i Milliye, 7 Teşrîn-i Evvel 1335/1919, No:6, s. 1.

59 Irâde-i Milliye, 15 Mart 1336/1920, No:30, s. 1.

60 Irâde-i Milliye, 12 Kanûn-1 Sânî,1336, No:20, s. 3. Bu gazetenin çeviri yazısında tarih 1335 olarak verilmiş ancak asıl nüshaya bakıldığında tarihin 1336 olduğu görülmüştür. 
rîn-i Evvel 1336) tarihli nüshasında bir taraftan Damat Ferit ve hükûmetine ciddi eleştirilere yer verilirken gerçekleşen hükûmet değişikliği de aynı gün haber olarak yer almıştır. Buna göre Sadarete Tevfik Paşa, Şûrâ-yı Devlet Reisliğine de Mustafa Arif Bey getirilmişti61 ${ }^{61}$ Görüldüğü gibi Anadolu basını İstanbul'da faaliyet gösteren Şûrâ-yı Devlet hakkında haberlere yer verirken Ankara'nın Şûrâ-yı Devlete ilişkin yaklaşımına yer vermemektedir.

TBMM'de Şûrâ-yı Devlet tartışmalarının en yoğun yaşandığı bütçe görüşmelerindeki tartışmalar da Hâkimiyet-i Milliye gazetesine yansımamıştır. 1337/1921 Bütçesi ile çıkan haber sadece bir paragraftır. Haberde Maliye Vekâletinin bütçe hazırlıklarına, diğger Vekâletlerin bütçe tekliflerini Maliye Vekâletine gönderdiğine, 1921 yll bütçesi gelirinin 75 milyon, giderinin ise 80 milyon olduğuna, aradaki 5 milyon liralık açı̆̆ın tasarruf ya da iç borçlanma ile kapatılacağına dair bilgi vermekle birlikte Şûrâ-yı Devlet özelinde bir bilgiye yer verilmemiştir ${ }^{62} .28$ Şubat 1921 yılında bütçe 63 milyon 18 bin lira olarak kesinleştiğinde aynı tarihte Hâkimiyet-i Milliye gazetesinde de "Büyük Millet Meclisi Müzâkeresi" başlı̆̆ı altında birinci ve ikinci celse tutanaklarına yer verilmiştir. Haberde Şûrâ-yı Devlet bahsi, "Şûrâ-yı Devlet Mesârif Bütçesinden Tenzîl” şeklinde haber alt başlığı içeriğinde kendine yer bulabilmiştir. Haberde birinci celse tutanaklarına atfen Şûrâ-yı Devlet bütçesinin müzâkeresine geçildiği, "Ve şimdiye kadar 'adem-i tesîsine binâen tenzîl edildiği”"ne yer verildiği görülmektedir. Bu durumda Şûrâ-yı Devlete bütçe ayrılmamasının gerekçesi bu Kurumun yeniden kurulamaması olarak gerekçelendirilmiştir. Aynı günkü gazetede yer alan diğer haber başlıklarının "Azerbaycan ve Bolşevikler", "İran, Şah, İngiltere", "Hindistan Galeyanı Tevsî Ediyor", Loyd George'a Âsî diyebilir miyiz", "Londra Murahhaslarımızdan Yeni Haber var" ve "Yine Yunan zulümleri soygun ve katil" gibi siyasi ve askeri içerikli haberler olduğu görülmektedir ${ }^{63}$. Günün koşullarına uygun olarak haber sayfalarında öncelik verildiği görülmektedir.

4 Temmuz 1337/1921 tarih ve 131 sayılı Şûrâ-yı Devletin Memûrîn Muhâkemâtına Müteaâllik Vezâifinin Sûret-i İâsı Hakkında Kanun ${ }^{64}$ ile Şûrâ-yı Dev-

61 Hâkimiyet-i Milliye, https://dspace.ankara.edu.tr/xmlui/handle/20.500.12575/1094 (Erişim tarihi. 25.10 2020). Ankara Üniversitesi Siyasal Bilgiler Fakültesi e-Arşivinde Milli Kütüphane uzantılı olarak önemli süreli yayınlar hizmete açılmıştır.

62 Hâkimiyet-i Milliye, 7 Şubat 1337/1921, No:102.

63 Hâkimiyet-i Milliye, 28 Şubat 1337/1921, No:120

64 Cerîde-i Resmîye, 11 Temmuz 1337/1921, No:20

Belleten, Aralık 2021, Cilt: 85/Sayı: 304; 1025-1071 
letin yetkilerinin TBMM'ye devredildiği pazartesi günü65 Hâkimiyet-i Milliye gazetesinde bir haber çıkmasa da ertesi gün 5 Temmuz 1337/1921'de gazete konuyu sayfalarına taşımıştır ${ }^{66}$. Haberde kanunun müzakeresi ve kabulüne değinilmekle birlikte Meclis Zabıt Ceridelerinde gördüğ̈ümüz Şûrâ-yı Devlet özelinde ayrıntılı bir tartışmalara yer verilmediği gibi daha da önemlisi toplam altı maddeden oluşan mezkûr Kanun da gazetede bütünüyle yayımlanmamıştır.

\section{TBMM'de Şûrâ-yı Devletin Yeniden Kurulması Sorunu}

Ankara Hükûmetinin Şûrâ-yı Devlete bakışını ortaya koymamıza imkân sağlayacak temel kaynak kuşkusuz TBMM Zabıt Cerideleridir. Daha önce başka bir çalışmada ${ }^{67}$ bu tutanaklar Şûrâ-yı Devlet bağlamında irdelenmiştir. Tespit edebildiğimiz kadarıyla ilk olması ve ceridelerde yer alan tartışmalara dikkat çekilmesi ve yerinde bazı tespitlerin paylaşılması bakımından bu çalışma değerlidir. Ancak zabıt ceridelerinin TBMM tarafindan günümüz Türkçesine yapılan çevirileri yanın da asıl nüshalarına da bakarak konuyu yeniden ele almak ve meseleyi doğru bir zeminde tartışmak adına bazı tespitlerin paylaşılmasının yerinde olacağı değerlendirilmektedir. Karahanoğulları, Meclisteki Şûrâ-yı Devlet tartışmalarına I. TBMM'de yer alan I. Grup ve II. Grup arasındaki muhalefet ekseninde yaklaşmaktadır $^{68}$. Yazar, Birinci Meclis’te Şûrâ-yı Devlet kurulmasına karşı gelişen muhalefetin o dönem Meclis içindeki siyasal bölünmeyi yansıttı̆̆ı, Şûrâ-yı Devlet aleyhinde söz alanların büyük çoğunluğunun ise II. Grup üyesi olduğu iddiasındadır. Ancak bu iddiayı teyit ve tevsik eden herhangi bir bilgi ya da belge bahsi geçen çalışmada sunulmamaktadır. Oysaki ilk TBMM'de yer alan I. ve II. Grupların Şûrâ-yı Devlet eksenli ayrışmaları kesinlikle mümkün değildir. 1336/1920 Muvâzene-i Umûmiye Kanununun görüşüldüğü zaman diliminde Şûrâ-yı Devlet ile ilgili yoğun tartışmaların yaşandığı ve 1 yıl sonra Şûrâ-yı Devletin bazı yetkilerinin 4 Temmuz 1337/4 Temmuz 1921 tarih ve 131 sayılı Kanun ile TBMM'ye devredilmesi ile tartışmalar o dönem için son bulmuştur. Tartışmaların yoğun yaşandığı 1920 ve 1921 yılları aynı zamanda işgal altında olan ve bağımsızlık mücadelesi verilen bir dönem ile çakıştı̆̆ı için mebusların ülke meselelerinde yekvücut hareket ettiği bilinmektedir. Şûrâ-yı Devleti destekleyen ve eleştirenler arasında bu tartışmaların bittiğinde ortaya çıkıp şekillenecek olan iki gruptan da ciddi sayıda mebus olduğu gözden

Hâkimiyet-i Milliye, 4 Temmuz 1337/1921, No: 226

66

Hâkimiyet-i Milliye, 5 Temmuz 1337/1921, No: 227

67

Onur Karahanoğulları, Türkiye'de İdari Yargı Tarihi, Turhan Kitapevi, Ankara 2005, s. $211-231$.

68

Karahanoğulları, age., s. 214-215.

Belleten, Aralık 2021, Cilt: 85/Say1: 304; 1025-1071 
kaçırılmamalıdır. TBMM'de II. Grup olarak bilinen Müdafaa-i Hukuk Grubu, 1922 yılının Temmuz ayında kurulmuştur. Bahsi geçen yaklaşıma göre II. Grup ete kemiğe bürünmeden yani hukuken ve resmen kurulmadan 1 yıl önce, Şûrâ-yı Devlet konusunda TBMM'de yer alan tartışmalara katılmıştır. Daha da ilginci bu tartışmalar büyük oranda bittiğinde TBMM'de Mustafa Kemal önderliğinde I. Grup dahi kurulmamıştır. Çünkü 1. Grubun kurulması 1921 yılı Mayıs ayında idi. Şûrâ-yı Devlet üzerinden siyasal bir ayrışma söz konusu değildir. Aksine bir tutumun anakronizm olacağı izahtan varestedir. Kaldı ki yazarın TBMM'de yer alan bu iki grubu anlatırken referans verdiği çalışmada ${ }^{69}$ da kendisinin de kabul ettiği üzere I. ve II. Grup arasında çatışma konularından birinin de Şûrâ-yı Devlet olduğuna dair hiçbir bilgiye yer verilmemektedir. Şûrâ-yı Devlete taraftarlık ya da karşıtlık için illa da bir sınıflandırma yapılacaksa bu durum Hükûmet Üyeleri ile bazı mebuslar arasında yapılabilir. Şöyle ki, zabıt ceridelerine de yansıdığı üzere Heyet-i Vekîle Üyelerinin tümü Şûrâ-yı Devlet’in TBMM tarafindan yeniden kurulmasına taraftardır. Bunun sebebi de kanaatimizce icra organınca/hükûmetçe, kamu hizmetlerinde Şûrâ-yı Devletin neye karşılık geldiğinin ve olmamasından doğacak boşluğun yol açacağı mağduriyetlerin işin sadece teşri/yasama kısmında bulunan menfi görüş sahibi bazı mebuslara göre daha sağlıklı analiz edilmesidir.

Şûrâ-yı Devletten kısmen bahseden bazı çalışmalarda Kurumun anlaşılmasına katkı sağlanmakla beraber zaman zaman ciddi yorum hataları da yapılmaktadır. Örneğin yakın bir dönemde yapılan Cumhuriyet Türkiye'sinin ilk dönem yönetsel gelişmelerini ortaya koyma çabası açısından yoğun bir tasnif çalışması ${ }^{70}$ da Şûrâyı Devlet bahsine yer verirken bazı hatalı analizlere yer vermektedir. Bahsi geçen çalışmada Şûrâ-yı Devlet "Adli Yönetim” başlığı altında ele alınmış ve "1921 yılı adli teşkilatlanmayla ilgili önemli düzenlemelerin de yapıldığı bir yıl olmuştur. Şûrayı Devlet’i ikame etmesi öngörülen Memurin Muhakemat Heyeti ve Encümeni’nin kuruluşu bu düzenlemelere örnek gösterilebilir.” denilmesi suretiyle Şûrâ-yı Devlet, adli teşkilatlanmanın ve bu yönde yapılan düzenlemelerin bir unsuru gibi gösterilmiştir. Oysaki 1868 yılında Şûrâ-yı Devletin kurulması ile birlikte Osmanlı hukuk sisteminde $i$ dari rë̈me ${ }^{71}$ geçiş için oldukça ciddi bir zemin hazırlanmıştır. Kıta Avrupa'sı ülkelerinde olduğu gibi "iki ayrı hukuk" ve buna bağlı olarak "iki ayrı yargı sistemi”, Fransa'dan mülhem olarak Türkiye'de 19. yüzyılın ikinci yarısından itibaren şekillenmeye başlamıştır. Bu noktadan hareket ile Şûrâ-yı Devlet ile ilgili

69 Ahmet Demirel, Birinci Meclis'te Muhalefet (İkinci Grup), İletişim Yay., İstanbul 1994.

70 Açıklamal Yönetim Zaman Dizini (1919-1928), C 1, s. 567.

71 Bu konuda ayrıntılı değerlendirme için bk. Eraslan, age., s. 216-219. 
düzenlemeler adli yargı ya da teşkilat bağlamında ele alınmamalıdır. Kaldı ki, bahsi geçen çalışmada yer verilen düzenleme 1921 yılında bir adli teşkilat düzenlemesi değil, Şûrâ-yı Devletin görev, yetki ve sorumluluklarından memur yargılamasına ilişkin olanlarının TBMM içinden seçilecek encümenlere devredilmesi işlemidir.

TBMM 23 Nisan 1920 yılında açılıp kısa bir süre sonra ülkenin kaderinde yegâne karar verici olmaya başlasa da gerek 1876 Anayasası ve gerekse daha önce yürürlüğe konulan kanunlar ile bir süre daha yoluna devam etmiştir. 1921 Anayasası'nın kabulünden on gün sonra Türkiye Büyük Millet Meclisi Reîsi sıfatıla Mustafa Kemal, Sadrâzam Tevfik Paşa’ya gönderdiği 30/1/1921 tarihli telgraf yazısında: "Kanûn-1 Esâsî'nin işbu mevâd (maddeler) ile teâruz (aykırı olmayan) etmeyen ahkâmı kemâkân mer'îyyü'l-icrâdır. (eskiden olduğu gibi yürürlüktedir) ${ }^{72}$ " demek suretiyle Kanûn-ı Esâsî’nin, Teşkilât-ı Esâsiye’ye aykırı olmayan hükümlerinin yürürlükte olduğunu bizzat vurgulamıştır. Bu kendine özgü durum ile 1921 ile 1924 arası dönem ilginç olarak Türkiye'de "iki anayasalı", 23 Nisan 1920 ile 4 Kasım 1922 arası dönem ise "iki hükûmetli" olmuştur. Çünkü belirtilen tarihler arasında 1876 Anayasası yürürlüktedir ve bir tarafta İstanbul Hükûmeti, diğger tarafta ise Ankara Hükûmeti ${ }^{73}$ vardır. Sebep ve sonuçları itibarılla burada durumun hukukiliği kadar hatta daha ziyade siyasal niteliği dikkat çekicidir.

İki hükûmetli dönemde Şûrâ-yı Devletin konumuna bakıldığında TBMM'nin açılmasından kısa bir süre sonra Şûrâ-yı Devlete olan ihtiyaç kendini göstermiştir. Şöyle ki, 19/5/1336 (1920) tarihinde Şûrâ-yı Devletin memur yargılamalarına ilişkin görevlerinin Meclis Dâhiliye, Nâfia ve Maârif Encümenlerinden seçilecek üyelerden oluşacak bir heyet tarafından yürütülmesine ilişkin bir "Dâhiliye Vekâleti Tezkeresi ${ }^{74 "}$ sunulmuştur. Bu tezkere karara bağlanamadığı gibi aynı konu yine "Dâhiliye Vekâleti Tezkeresi" olarak 3/6/1336 (1920) tarihli Meclis Gündemine de tekrar alınmış ancak burada da karara bağlanamamışıır ${ }^{75}$.

Diğger taraftan 22 Ağustos 1336/1920’de Dâhiliye Vekîli Dr. Adnan Beyin kaleme aldığı Şûrâ-yı Devletin Teşkîline İlişkin Lâyihanın Esbâb-ı Mûcibesinde (gerekçe), mezkûr Kurumun görev, yetki ve sorumluluklarının altı çizilmiş ve TBMM

72 Mustafa Kemal Atatürk, Nutuk (1919-1927), 4. baskı, Atatürk Araştırma Merkezi Yay., Ankara 1997, s. 376.

73 Ayrıntılı bilgi için TBMM Hükûmetini tarihi oluşum koşulları içerisinde ele alan ve bu Hükûmetin görev, yetki ve sorumluluklarını etraflıca tahlil eden bir çalışma olarak bk. Rıdvan Akın, TBMM Devleti (1920-1923), İletişim Yay., İstanbul, 2001.

74 TBMMZC, İçtima: 18, (19.5.1336), Gelse 1, s. 345.

75 TBMMZC, Içtima: 23, (3.6.1336), Celse 1, s. 69. 
Hükûmetinin Şûrâ-yı Devlet görevlerini ihmal ettiği vurgulanmıştır ${ }^{76}$. Lâyihanın 1. maddesi Tanzimat, Mülkiye ve (Nâfia/Maliye/Maârif) Dairelerinden oluşan Büyük Millet Meclisi Riyâsetine merbût (bağlı) bir yapı önerilmiş ve 16.09.1336 (1920)'de Heyet-i Vekîle tarafindan da uygun bulunan lâyiha, Meclis Reîsi Mustafa Kemal Paşa’nın imzası ile 27.09.1336 (1920)'de Riyâset-i Celîle’ye gönderilmiştir ${ }^{77}$. Ancak bu lâyiha Mecliste kabul görmemiştir. Meclis Adliye ve Dâhiliye Encümeni tarafindan ret gerekçesi, mezkûr Kurumun görevlerinin Heyet-i Vekîle ve TBMM tarafindan üstlenilebileceği noktasındadır ${ }^{78}$.

Ankara Hükûmetinin Şûrâ-yı Devletin yeniden teşkîli noktasında sarf ettiği acil ve ciddi çabalar zabıt ceridelerinden ${ }^{79}$ rahatlıkla anlaşılmaktadır. Şöyle ki, 29.1.1337/1921 tarihli 139. İçtimaya Şûrâ-yı Devlet tartışmaları damga vurmuştur. Bu görüşmeler başladığında "Şûrâ-yı Devlet Teşkîli Hakkındaki Kanun Lâyihasının Süratle Müzâkeresine Dair Heyet-i Vekîle Riyâsetinden Mevrûd Tezkere" ile adı geçen lâyihaya ilişkin "Dâhiliye ve Adliye Encümenleri Mazbataları" Meclis Gündeminde yer bulmuştu. Aynı tarihte Bütçe Kanunu da Meclis Gündeminde yer alsa da Canik Mebusu Nafiz Bey, Meclis Başkanlığına şu takrîri/ önergeyi vermiştir: "Şûrâ-yı Devlet teşkîline dair olan mevâddın, mevâdd-ı saîreye tercihân müzâkeresini teklif ederim ${ }^{80}$." Nafiz Bey; "Şûrâ-yı Devletin önceden özellikle de memur yargılamalarında çok önemli görevleri bulunduğunu, Ankara Hükûmetinin kuruluşundan önce ya da sonra yargılanan memurların evrakının sürüncemede olduğu, bir merci-i tedkîkin olmamasından bahisle birçok memurun süründüğünü, Şûrâ-yı Devlet de teşkîl edilemediğinden dolayı bu adamların mağduriyetinin temadi eylediğini (devam edegeldiğini) ifade etmiş olup Şûrâ-yı Devletin teşkîli hususunun diğer tüm gündeme (Bütçe dâhil) mukaddem (öncelikli) olarak ele alınmasını" teklif ettiği önergesini bu şekilde gerekçelendirmiştir ${ }^{81}$.

Önerge, oturumu yöneten Reis Hasan Fehmi Bey tarafindan onaya sunulmuş ve oy çokluğu ile kabul edilmiştir. Daha sonra bununla da yetinilmemiş ve akabinde Dâhiliye Vekîli Dr. Adnan Bey, müstaceliyetle/ivedi olarak konunun müzakeresini

76 Toplam dokuz maddeli lâyiha ve gerekçe için bk. TBMMZC, İçtima: 45, (2.7.1337), Gelse 2 sonunda yer alan Ek (S. Sayısı: 3)

77 TBMMZC, İçtima: 45, (2.7.1337), Celse 2 sonunda yer alan Ek (S. Sayısı: 3)

78 TBMMZC, İçtima: 45, (2.7.1337), Celse 2 sonunda yer alan Ek (S. Sayısı: 3)

79 Şûrâ-yı Devlet Lâyiha, mazbata ve tezkeresi üzerine tafsilatlı müzakereler için bk. TBMMZC, Içtima: 139, Gelse 1 ve 2 (29.1.1337), ss. 407-409 ve 417-432.

80 TBMMZC, İçtima: 139, Celse 1, (29.1.1337), s. 409.

81 TBMMZC, İçtima: 139, Celse 1, (29.1.1337), s. 407-408. 
istemiş ve yapılan oylamada bu talep de oy çokluğu ile kabul edilmiştir. Ancak bu önergelerin kabulü öncesinde birinci celse oturumunda ilginç tartışmalar yaşanmıştır. Tokat Mebusu Mustafa Bey ile Konya Mebusu Musa Kazım Efendi, Meclisin en birinci görevinin bütçe olduğunu bütçeye tercihen hiçbir şeyin müzakeresini doğru bulmadıklarını ifade etmişlerdir ${ }^{82}$. Yapılan görüşmelerde muhalif bir duruş olarak Izmit Mebusu Hamdi Namık Bey ve Konya Mebusu Musa Kazım Efendi, Şûrâ-yı Devletin teşkîline luzûm olmadığını, Şûrâ-yı Devletin teşkîlinde bir fayda bulunmadığını ifade etseler de Nâfia Vekîli Ömer Lütfi Bey, Gümüşhane Mebusu Hasan Fehmi Bey, Malatya Mebusu Feyzi Efendinin verdiği destek ile Şûrâyı Devlet lehine hareket edenler etkili olmuştur. Malatya Mebusu Feyzi Efendi: "Şûrâ-yı Devlet Kanununun müzakeresi en ehem ve elzem (en önemli ve gerekli) bir meseledir. Altı, yedi aydan beri hapiste yatan memurlar vardır. Onların ahvâlini düşünmeliyiz ve hem de müstaceliyetle çıkarmalıyı" şeklinde Şûrâ-yı Devletin yeniden teşkîlini desteklerken, Karesi Mebusu Vehbi Bey’in Şûrâ-yı Devlet için bir ısrarı olmamakla beraber "... On aydan beri mercisiz kalmış iş olmaz. Büyük Millet Meclisi her şeye merci gösterdiği halde Şûrâ-yı Devlet yerine kaim olacak bir daire, bir makam gösteremez ise bu gayri mantıki bir hareket olur ${ }^{83}$ " demek suretiyle memur yargılamalarında adaletin gecikmesini eleştirmiştir.

Şûrâ-yı Devlet ile ilgili tartışmalara aynı gün (29.1.1337/1921) ikinci celse görüşmelerinde yine Hasan Fehmi Beyefendi'nin riyâsetinde devam edilmiştir. Birinci celse tartışmaları daha çok Şûrâ-yı Devletin Bütçe Kanunundan önce görüşülmesi meselesiydi ki bu durum Şûrâ-yı Devlet lehine sonuçlanmıştı. II. Celse müzakerelerinde ise mezkûr Kurumun görev, yetki ve sorumlulukları tarihsel pratiği bağlamında derinlikli olarak ele alınmış ve Şûrâ-yı Devlete yönelik bir taraftan ciddi savunular getirilmiş diğer taraftan ise oldukça sert eleştiriler yöneltilmiştir. Aşağıda mebusların konuya yaklaşımları iki ana başlık altına verilerek incelenecektir.

\section{Şûrâ-yı Devlet Ehem ve Elzemdir (En önemli ve gerekli) Görüşü}

Şûrâ-yı Devlet Kanunu Lâyihası ile Dâhiliye ve Adliye Encümeni Mazbataları görüşülürken Mecliste taban tabana zıt oldukça sert tartışmalar yaşanmıştır ${ }^{84}$. Tartışmalar daha ziyade Dâhiliye Encümenlerinin hazırladı̆̆ı mazbata etrafinda şekillenmiştir. Çalışmanın bu kısmında Heyet-i Vekile Üyeleri ile mebusların

82 TBMMZC, İçtima: 139, Celse 1, s. 408-409.

83 Bahsi geçen ifadeler için bk. TBMMZC, Içtima: 139, Celse 1, s. 409.

84 Çalışmada bu kapsamda yer verilen tartışmalar TBMMZC, İçtima: 139, Gelse 2, (29.1.1337), s. 417-431'de yer almaktadır. Tutanağın farklı sayfalarında yer alan mebus görüşlerinin aynı mebus için art arda verilmesi çalışmada tercih edilmiştir. 
Şûrâ-yı Devlet üzerine yaptığı tartışmaların geniş özetine yer verilmesi ve onların görüşlerinin sonuna kendi tespitlerimizin eklenmesi tercih edilmiştir. Çünkü meseleyi tartışan mebuslar bu ihtisas Kurumunun fotoğrafinı gayet derinlikli analizlerle ortaya koymuşlardır. Bir anlamda tartışmaların yapıldığı dönemde Şûrâ-yı Devletin 52 yıllık sergüzeşti ortaya konulmuştur. TBMM'nin bakış açısını yansıtması açısından bu durum son derece önemlidir. Bu bağlamda;

Dâhiliye Vekîli (İstanbul Mebusu) Dr. Adnan Bey; Heyet-i Vekîle'nin Şûrâ-yı Devletin görevli olduğu meselelerin altından kalkamayacağını, memur yargılamalarının geciktiğini ve bu durumun pek çok mağduriyete yol açtığını, Şûrâ-yı Devletin iki büyük vazifesi olduğunu, birinin memurin muhâkemâtı meselesi olduğu, Elyevm (Şu anda) ne kadar kanun varsa hepsinde aşağı yukarı Şûrâ-yı Devletin isminin geçtiğini, kanunların tefsirinin şimdiye kadar Şûrâ-yı Devlete havale edilmiş bir hak olduğunu Meclisin şimdi bu durumu başka bir şekilde kararlaştırabileceğini ifade etmiştir. Devamla; Şûrâ-yı Devletin birçok görevi olduğunu örneğin kişiler ile hükûmet arasındaki ihtilafi hakkaniyete uygun olarak giderdiğini, gelinen noktada Vekîl arkadaşlarının tamamının Şûrâ-yı Devletin görevlerini "Heyeti Vekîle'nin yapmasının imkânı yoktur" dediğini şimdi Heyeti Vekile’nin "Şûrâ-yı Devletin lüzûmuna kâni” olduğunu Şûrâ-yı Devletin en basit masrafla olan şeklinin kabul edilmesi gerektiğini aksi takdirde Heyet-i Vekîle’nin bu işlerle meşgul olmak için vaktinin müsait olmadığını, "ifade etmiştir ${ }^{85}$.

Nâfia Vekîli (Amasya Mebusu) Ömer Lütfi Bey; Kanunların tanzim ve tefsiri meselesinde hakkın Meclis-i Âlî̀de olduğunu, bunu üzerine alabileceğini ancak memur muhâkemâtına konu gelince, esasen memurların şahsi işlerden dolayı mahkemeye verildiğini ancak "vazîfe-i memûreleri nokta-i nazarından isnâd olunan ahvâlden" dolayı Şûrâ-yı Devletçe tahkikat yapıldığını memurun muhakemeye sevkini icap ettirip ettirmeyeceği anlaşılsın diye "tahkîkat-ı evveliye (Ön inceleme)" yapıldığını memur suçlarında yapılacak tahkîkat-ı evveliyede bittabî bir ihtisas gerektiğini bunun inkâr edilemeyeceğini Şahıs veya şirketlerin aldığı imtiyâzların usulünce merbût (bağlı) olduğu dairede tetkik olunduğunu sonuçta Heyeti Vekîle tarafindan kabul ya da reddedildiğini bu noktada Şûrâ-yı Devlete ihtiyaç bulunmadığını ancak yapılmış, verilmiş olan ruhsatnamelerden, imtiyazlardan doğan hükûmet ile eşhâs arasındaki ihtilâfatı halletmenin bir ihtisas gerektirdiğini ifade etmiştir ${ }^{86}$.

85 Ayni yer, s. 417-418.

86 Ayni yer, s. 426. 
Yukarıdaki ifadelerle Ömer Lütfi Bey, Şûrâ-yı Devletin bir İhtisas Kurumu olduğunun altını çizmekte, memur suçlarına ilişkin ön incelemeyi (tahkîkât-1 evveliyeyi) adliye mahkemelerinin hakkıyla yapamayacağını vurgulamaktadır. Nâfia Vekîli Ömer Lütfi Bey de, Dâhiliye Vekîli Adnan Bey gibi düşünmekte, tâli derecedeki bu işleri (Şûrâ-yı Devletin görevleri) Encümen ve Meclis üzerine alırsa zannederim ki, "vazîfe-i asliyesinde iyi iş göremez" tespitinde bulunmakta ve Heyet-i Vekîle'nin bunlara vakti olmadığından bakamayacağını, bu konuda fikir birliği bulunduğunu ifade etmiş ve bu çerçevede bir Şûrâ-yı Devlet teşkîline taraftar olduğunu söylemiştir ${ }^{87}$.

Nafîz Bey (Ganik Mebusu); Şûrâ-yı Devletin görevlerinin oldukça önemli olduğunu "Bu vezâif-i mühimmenin Ankara Hükûmetinin teessüs ettiği zamandan beri muattal (atıl kalmış)" kaldığını, bu görevlerin Heyet-i Vekîle'ye tevdi edildiği takdirde, Heyet-i Vekîle daha önemli devlet görevlerini bırakıp bu türden işlere vakit bulamayacağını, diğer taraftan Şûrâ-yı Devletin hükûmetle eşhâsa taallûk eder bir takım görevlerinin davalı taraflardan birine (hükûmete) bırakılamayacağını, bunun hukuka, hikmete ve mantığa aykırı olacağını ifade etmiştir ${ }^{88}$.

Nafiz Bey'e göre bu bağlamda "bir Şûrâ-yı Devlet tesisi derece-i vücûptadır." Nafîz Bey, Şûrâ-yı Devletin bütünüyle lâğvedilmesine karşı olduğu gibi yeniden teşkîl edilmesine de karşı çıkmışır. Bu Kurumun görev ve yetkilerinin Heyet-i Vekîle'ye bırakılmasını da doğru bulmamıştır. Onun önerisi "masrafsız bir Şûrâ-yı Devlet teşkîli’"dir. Bunun ise ancak Meclis-i Âlî̀den intihapla mümkün olabileceği kanaatindedir. Üçer kişiden mürekkep olarak, üç daireden ibaret bir Heyet-i Umûmiye teşkîl ve te'sis edilebilip âzaların da Heyet-i Kirâm (TBMM Üyeleri) içerisinden seçildiğinde ancak hakikî ve tarafsız bir Şûrâ-yı Devlet olabileceğini, "muamelât-ı devlette milletin arzusu veçhile temşiyet ${ }^{89 "}$ edilmiş olacağını ve bu

87 Ayni yer, s. 427.

88 Ayni yer, s. 418-419.

89 TBMM Kütüphanesi açlk erişiminde yer alan zabıt ceridesi (29.1.1337 tarihli 139. İçtima ve 2 no.lu celse) TBMM tarafindan günümüz Türkçesine çevrilirken Canik Mebusu Nafiz Beye atfen s. 419'da "teşmiyet (aksırana hayır dua etmek)" olarak okunan kelimenin doğrusunun aynı zabıt ceridesinin Osmanlıca metnine bakıldığında (s. 512) "temşiyet (yürütme/idare etme/icra)" olduğu görülür. Bu durum ilk bakışta basit bir okuma hatası olarak görülebilir. Ancak "temşiyet kavramı" kamu hukukuna ait bir kavramdır. Devletin tasarrufları ile ilgili bir konudur. Temşiyet tasarrufları, devletin ve diğer kamu kuruluşlarının olağan bir tüzel kişi sıfatıyla, egemenlik kudretinden sıyrılarak bireyler gibi, özel hukuk kurallarına uygun olarak yaptığı tasarrufları tanımlar. Temşiyet kavramı ve tasarrufları için bk. Sıdık Sami Onar, İdare Hukukunun Umumî Esaslan, C 1, (2. baskı), İsmail Akgün Matbaası, İstanbul 1960, s. 39; Ejder Yılmaz, Hukuk Sözlï̆̆ü, (3. baskı), Yetkin Yay., Ankara 2005, s. 688. Şûrâ-yı Devlet ile ilgili hukuki terimler günümüz Türkçesine çevirirken oldukça dikkatli davranmak gerekir. Aksi takdirde konunun esasına etki edecek yorum hatalarına zemin hazırlanabilir. 
usul kabul edilmezse, Dâhiliye Vekîli Adnan Beyin önerdiği bir Şûrâ-yı Devlet teşkîli için Hazine-i Devletten birçok para vermek iktiza edeceğini/gerekeceğini buna da bütçenin müsait olmadığını bu doğrultuda en eslem-i tarîkin/en sağlam yolun Meclis-i Âliden intihap/seçme olduğunu ifade etmektedir ${ }^{90}$.

Celâleddin Arif Bey (Erzurum Mebusu); Kanunlarımızın esasında Şûrâ-yı Devletin gayet mühim bir yeri olduğunu, Şûrâ-yı Devletin kanunlarımıza göre Sadrâzamın refakatinde bir Heyet-i İstişâre olduğunu ve bu Heyet-i İstişârenin birçok görevi olduğunu ifade ettikten sonra bu görevlerden en mühimmi, "kavânin-i idâriyenin tefsîri meselesidir" demiştir. Diğer taraftan devlet daireleri arasında meydana gelen ihtilâfatın hâllinde, maadin meselelerinde de görevli olduğunu maadin meselelerinde Şûrâ-yı Devletin doğrudan doğruya bir mahkeme hükmünde olduğunu ve orada verdiği kararların kazâî nitelik taşıdığını ifade etmiştir. Celâlettin Arif Bey, devamla imtiyâzat ve memûr muhâkemâtı hususlarının da Şûrâ-yı Devlete ait olduğunu Heyet-i Vekîle’nin Encümene göndermiş olduğu kanun taslağının sorunları çözmekten uzak olduğunu ve "Şûrâ-yı Devletin Doğrudan doğruya bi-taraf bir heyet olmak üzere teşekkülü lâzım gelir” demek suretiyle lâyihada önerilen Dâhiliye müsteşarı ve müdiran riyaseti altında ve Dâhiliye müdiranından ve bir takım zevattan mürekkep yapının "bi-taraf olamayacağının" altını çizmiş ve "Devlet makinesini yürütmek için Şûrâ-yı Devlete lüzûm-ı kat'i vardır" demiştir ${ }^{91}$.

Celâleddin Arif Bey, görüşlerine devamla zamanımızın ihtisas zamanı olduğunu her şeyde bir ihtisasa lüzum bulunduğunu bu bağlamda "Şûrâ-yı Devletin doğrudan, doğruya, bir ihtisas müessesesi” olduğunu, TBMM içinden seçilen heyetlerin bu görevleri gereğine uygun yerine getiremeyeceğini ifade etmiştir. Diğer taraftan fertlerin sorun yaşadığı hususlarda pek çok mebusun "efendim mehâkim vardır, mahkemeye gitsinler" yaklaşımına da karşı çıkmış ve mahkemelerin masraflı olduğunu evvelâ rubu (dörtte bir) harç vermek gerektiğini, hâlbuki Şûrâ-yı Devletin bu meseleleri parasız hallettiğini halkın daha fazla müstefîd oluğunun altını çizmiştir. Kavânîn-i idârede teamülü Şûrâ-yı Devlet mukarreratının temin edeceğini, kanunun meskût (cevap veremediği) olduğu birçok mesailin bulunduğunu ve Şûrâ-yı Devlet kararlarının doğrudan doğruya bir teamül esasını teşkîl ettiğini ifade etmiştir ${ }^{92}$.

Görüldüğü üzere Canik Mebusu Nafiz Bey, tarafsız ve masrafsız Şûrâ-yı Devlet teşkîline formül olarak TBMM'yi adres göstermiştir. Onun gibi Şûrâ-yı Devlete

90 Ayni yer, s. 418-419.

91 Aynı yer, s. 418.

92 Ayni yer, s. 423-424. 
taraftar olan Celâleddin Bey, ise yöntem açısından farklı bir yaklaşıma sahiptir. TBMM üyelerinin yoğun meşguliyetinin Şûrâ-yı Devletin görevlerini hakkıyla yerine getirmeye engel olacağını, ihtisas kurumu Şûrâ-yı Devletin tarafsız bir mahiyette kurgulanması gerektiğinin altını çizmektedir. Tıpkı Dâhiliye Vekîli Dr. Adnan Bey ve Nâfia Vekîli Ömer Lütfi Bey gibi Nafiz ve Celâleddin Arif Beyin de Şûrâ-yı Devletin gerekliliğine olan inancı tamdır. Aralarındaki fark teşkîl şeklidir. Şûrâ-yı Devletin elyevm (şu anda) ehem (en önemli) ve en elzem (gerekli) bir daire olduğunu iddia eden Feyzi Efendi (Malatya Mebusu) ise, çünkü pek çok memûrînin evrakının yığıldığını, biri Şûrâ-yı Devletin lüzûmu, diğgeri Şûrâ-yı Devletin mesârifi olmak üzere şimdi Mecliste bu iki hususun tartışıldığını, Şûrâ-yı Devletin âzalarını, Nafiz Beyin dediği gibi Meclisten seçmek suretiyle, Şûrâ-yı Devlet teşkîlinde masraf edilmeyeceğini belirtmiştir ${ }^{93}$.

Zekâi Bey (Adana Mebusu); Şûrâ-yı Devlet müzâkeratının Meclis-i Âlî’yi bu kadar işgal edeceğini tahmin etmediğini, herkesin malûmudur ki bunun bir Devlet teşkilâtı için lâzım bir mesele olduğunu, en ziyâde lüzûmu "Efrâd ile Devâir-i Hükûmet arasında hudus eden (meydana gelen) ihtilâfatın merci-i hâl ve faslı olması" itibariyle olduğunu belirttikten sonra her vesile ve her sebeple ahaliyi mahkemelere müracaata mecbur etmemek için Şûrâ-yı Devlet teşkilâtına ihtiyaç ve lüzum olduğunu söylemiştir.

Zekâi Bey devamla; Şûrâ-yı Devletin başlıca üç vazifesinin "Kavânin ve nizâmat lâyihalarının tanzîmi, kavânin ve nizâmatın tefsîri, sonra efrâd ile devâir-i hükûmet arasındaki mesâilin hâl ve fash ve bir de memûrîne ait evrâkın muhâkemesi değil tedkîki olduğunu" ifade ettikten sonra kanunların yorumlanma işinin devamlı toplanan Meclis-i Âlî’ ye ait olduğunu, bu noktada Şûrâ-yı Devlete lüzum bulunmadığını ancak memurinin muhakemesi için bir heyete esasen ihtiyaç bulunduğunu, devâir ile ahâli arasında zuhûr eden ihtilâfin her birisinin mehâkime müracaatla halledilemeyeceğini ifade etmiştir. Şûrâ-yı Devletin lüzumunun birçok kez nitekim seferberlik esnasında bilhassa askerlik meselesinde görüldügünü belirttikten sonra konuyu bir örnekle somutlaştırmıştır. Ahz-i asker (askere alma) şubelerinin rast geldikleri yerde herkesi asker etmeye çalıştı̆̆ını, bunu vazife bildiklerini, durumdan memnun olmayıp Şûrâ-yı Devlete müracaat edenlerin, o kanunları mevki-i müzâkereye aldırdığını, tetkik edildiğini, Şûrâ-yı Devlet, kanunu tefsir ederek Harbiye Nezaretine tebligat icra ettiğini vurgulamıştır ${ }^{94}$.

93 Ayni yer, s. 421.

94 Aynu yer, s. 422. 
Ífadelerden de anlaşılacağı üzere Harbiye Nezareti ve diğger nezaretlerin alınan kararlara uyduğu dikkate alındığında Şûrâ-yı Devlet, merkezi idarenin bir parçası olsa da aldığı kararlara gösterilen itibar ile idarenin fevkinde bir konuma sahip olmuştur. Daha da önemlisi bu durum fertlerin hukukunun devlete karşı Şûrâ-yı Devlet eliyle korunduğunun en önemli göstergesidir.

Şahıslar ile hükûmet arasındaki anlaşmazlıklarda yetkinin Şûrâ-yı Devletten alınmasının sakıncalarına değinen Zekâi Bey, fertlerin akdedilmiş kontrat ve imtiyazı mevcut ise onu Şûrâ-yı Devlete götürebildiğini, Şûrâ-yı Devletçe tetkik edilip karar verilebildiğini, Şûrâ-yı Devletin ilgili devlet dairesine "haksızsın diyebildiğini" bunun için yani "eşhâsın muhâfaza-i hukûku namına" böyle bir heyet-i tedkîkin her koşulda gerekli olduğunu ifade etmiştir.

Bu ifadelerden ve tarihsel pratiğinden hareketle Şûrâ-yı Devletin fertler ile hükûmet arasında yaşanan uyuşmazlıkların çözümünde gayet önemli bir rol oynadı̆̆ı, bu çerçevede hakkı ihlal edilenlerin hak aramada başlıca mercii olarak Şûrâ-yı Devlete müracaat ettikleri görülmektedir. Yukarıda yer verildiği üzere Zekâi Bey ile Gelâleddin Arif Bey, hakkı ihlal edilenlerin haklarını arama vasıtası olarak Şûrâ-yı Devlete müracaat ettiklerini, bu yöntemle hak aramanın mahkemelere göre daha masrafsız ve kolay olduğuna dikkat çekmişlerdir.

\section{Köhnemiş Şûrâ-yı Devlet Ortadan Kaldırılmalı Görüşü}

TBMM'de yaşanan Şûrâ-yı Devlet tartışmaları taraftarlık veya karşıtlı ekseninde şekillenmişti. Çalışmanın bu alt başlı̆̆ı altında yer alan menfî mebus görüşlerinin de geniş özetine yer vermek tercih edilmiştir. Bu durum taban tabana zıt yaklaşımların mukayeseli analizine imkân tanıyacaktır. Itiraz edenlerin TBMM ve mahkemeler varken Şûrâ-yı Devlete ihtiyaç olmadığı, bu Kurumun devlete ve millete gereksiz külfet yüklediği noktasından hareket ettikleri görülmektedir. Bu bağlamda;

Dâhiliye Encümeninde de yer alan mebus Mustafa Bey (Karahisar-i Şarki); "memûrîn muhâkemâtının tedkîki için o memurların ait oldukları vekâlet müdirânından yani o memurları tâyin edecek olan müdirândan bir heyet teşekkül etmek" fikrine encümenin muhalif olmakla birlikte memurların muhâkemât sürecine Şûrâ-yı Devlet ya da herhangi bir idari bir makamın dâhil edilmesini doğru bulmamış ve "Zaten bi'l-umûm mevâd-ı cezâiyye'yi îtâ salâhiyetini haiz mehâkim Adliye Nezâretine aittir. Bu tabiî bir meseledir. Her devlette de böyledir. Şimdi bundan memûrînin istisnası ile bunların tahkîkatının ayrıca memûrîn-i mülkiye tarafından takdiri hiçbir sebep ve hikmete müstenid değildir" diyerek memur yar- 
gılamasının tümüyle adliyelere bırakılmasını dolayısıyla da "tek yargı sistemini" savunmuştur ${ }^{95}$.

Vehbi Efendi (Konya Mebusu); Devr-i sabıkta birçok boş sandalye bulunduğunu Bâb-1 Âlî’nin mühim ve muteber kişilerinin bu boş sandalyelere gönderildiğini, milletten milyonlarca para çıktığı halde işlerin sürüncemede kaldığını, şimdi milletin parasının olmadığını ve boş adam oturtacak sandalyesinin de bulunmadığını binâenaleyh böyle bir teşkilâta (Şûrâ-yı Devlet) da lüzum kalmadığını ifade etmiştir. Adnan, Celâleddin Arif ve Nâfiz Beyefendilerin Şûrâ-yı Devlet teşkîlatının derece-i vücûpta olduğundan bahis buyurduklarını ancak vâcip (zorunlu olan) şöyle dursun, mendûp (olması gerekmeyen) bile olmadığını ifade ettikten sonra mahkemenin bir olması gerektiğini, memurların mahkemesinin başka, efrâd-ı nâsın mahkemesinin başka olmaması gerektiğini, eğer mahkemelere itimat yoksa mahkemelerin düzeltilmesi gerektiğini, itimadımız varsa böyle tefrika olmaması gerektiğini ifade etmiştir ${ }^{96}$.

Şûrâ-yı Devlete gerek yoktur diyen Vehbi Efendi: "Şimdi Şûrâ-yı millet vardır. Şûrâ-yı millet varken Şûrâ-yı Devlete lüzûm yoktur. Şûrâ-yı Devlete lüzum ve ihtiyaç bir Şûrâ-yı Millet yok iken ve devr-i istibdatta idi” demiş ve kanunların tefsîri meselesine gelince, kanunu yapan bu Meclisin kanunu da tefsîr edebileceğini belirttikten sonra Nafiz Beyin Meclisin içinden üçer kişilik birer heyet ayrılsın fikrine (memûr muhâkemâtı noktasında) iştirak ettiğinin altını çizmiştir.

Vehbi Bey (Karesi Mebusu); Müstemirren münakit (devamlı toplanan) bir Meclis olduktan sonra Şûrâ-yı Devletin teşkîline lüzûm olmadığını buna mantığın müsaade etmeyeceğini, aynı şekilde maadin ve imtiyâzât-1 sâire gibi Şûrâ-yı Devlete muhavvel bu gibi vezâifi de her zaman Meclisin halledebileceğini ifade etmiştir. Memûrun muhâkemâtına yönelik ise mahkemenin bir olduğunu ancak memûrînin vazîfe-i memûrelerinden mütevellit usullerden dolayı bir nizâma tâbi olduklarını yoksa diğer cerâim-i âdiyelerinden dolayı hiçbir zaman memurların fertlerden ayrılmadıklarını bu usulün (memurun muhakematı/tahkikat-ı evveliye) değiştirilmesine lüzum olmadığını, hatta umur-ı idâre daha iyi bir surette tedvîr edilmek isteniyorsa bu tarzın bugün için de devam etmesinin gerekli olduğunu ifade etmiştir ${ }^{97}$.

Hüseyin Avni Bey (Erzurum Mebusu); Şûrâ-yı Devlet teşkilâtının devr-i sabık (önceki devir) icraatdan olduğunu ve şimdi hiç bir kıymetinin kalmadığı-

95 Ayn yer, s. 417.

96 Aym yer, s.419

97 Aynu yer, s. 419-420.

Belleten, Aralık 2021, Cilt: 85/Sayı: 304; 1025-1071 
nı, lâğv (ortadan kaldırılması) edilmesi gerektiğini, Şûrâ-yı Devletin, memurların muamelâtını suhuletleştirmekten (kolaylaştırmaktan) ziyade tas'ib (zorlaştırdığını) ifade etmiştir ${ }^{98}$.

Mehmet Şükrü Bey (Karahisar-1 Sahip Mebusu); Kanunlarımızın hemen her noktasında Şûrâ-yı Devlete tesadüf edildiğini diğer rüfekâ-yı kirâm (şerefli dostlar/mebuslar) gibi, Şûrâ-yı Devletin ihdâsı taraftarı olmadığını milletin ihtiyaç duyduğu değişiklikler yapılıncaya kadar hali hazırdaki kanunların selâmetle tatbikini temin için Şûrâ-yı Devlet vezâifini görecek bir daire bulunmasının zaruri olduğunu bu zaruretin, her vekâlette bulunan hukuk müşavirliklerinin doğrudan Heyet-i Vekile Riyâsetine merbût (bağlı) olduğunda karşılanabileceğini, böylece Şûrâ-yı Devlet teşkîlinden ve bütçe meselesinden kurtarılacağını ifade etmiştir ${ }^{99}$.

Halil İbrahim Bey (Antalya Mebusu); “. . Binaenaleyh bendenizce de hiçbir suretle Şûrâ-yı Devlet teşkîline lüzûm yoktur.” diyerek görüşünü dile getirmiştir ${ }^{100}$.

Musa Kâzım Efendi (Konya Mebusu); Önceki kanunlar dikkate alındığında Şûrâ-yı Devlete ihtiyaç bulunabileceğini ancak devamlı toplanan bir Meclis ve "Teşkilât-ı Esâsiye Kanununda daimî olarak Meclisin murakıp vaziyetinde bulunacağı teemmül (ümit)" edilirse Şûrâ-yı Devlete bugün pek büyük bir ihtiyaç kalmadığına kanaat edileceğini, lüzûm-ı muhâkeme veya men-i muhâkeme kararlarının Şûrâ-yı Devletçe tasdîk veya reddinin memurlara bir hizmet değil, bilâkis kısmen Mecâlis-i İdârede ve kısmen Şûrâ-yı Devlette evrak dolaşıp geleceğinden ve takip edilemeyeceğinden aylarca sürüncemede kalacağını bu bağlamda zaten doğrudan doğruya "tahkîkât-1 evveliyeyi (ön inceleme)" de adliyelere vermenin ve kazayı tevhit etmenin en doğru, tabiî bir usul olduğunu ifade etmiştir ${ }^{101}$.

Gerek Vehbi Beyin ve gerekse Musa Kâzım Efendinin tevhîd-i kazâ (yargı birliği) vurgusu oldukça dikkat çekicidir. Bu noktadan bahisle Şûrâ-yı Devlete lüzûm kalmayacağını belirtmektedir.

Hasan Basrî Bey (Kayseri Mebusu); Şûrâ-yı Devlete yönelik en sert eleştirilerin sahibi Hasan Basri Bey, idari teşkilat içinde en köhne, en eski, en kokuşmuş bir teşkilatın yeniden ihya edilmeye çalışıldığını, bugün halk idaresini kabul etmiş kafaların, Şûrâ-yı Devleti katiyen kabul edemeyeceğini, çünkü Şûrâ-yュ Devletin, halk idaresinden ayn bir teşkilât olduğunu, Meclis-i Âlî̀nin (TBMM) hem icraî hem de teşriî

\footnotetext{
98 Ayni yer, s. 420.

99 Aym yer, s. 420-421.

100 Ayn yer, s. 421.

101 Aynu yer, s. 422.
} 
salâhiyeti haiz (yetkiye sahip) olduğuna vurgu yapmış ve Meclis-i Âlî varken bir de Şûrâ-yı Devletin olmasının pek gülünç olacağını belirtmiştir. Devamla, Şûrâyı Devletin bütün görevlerini TBMM'nin yapabileceği bir yerde bunun 'vebâl-i azim (büyük vebal)" olduğunu köhne Şûrâ-yı Devlet teşkilatının şimdiye kadar ne ihtisas gösterdiğini ne de bu millete nâfi bir iş çıkardığını sadece mütekaidinin (emeklilerin) ve mazûlinin (azledilmişlerin) iaşesine medar (yarayacak) olacak sandalyeler halinde kalmış olduğunu Şûrâ-yı Millet varken Şûrâ-yı Devlet istemediklerini, böyle bir Kuruma bütçe ayrılmaması gerektiğini, bunun israf kaynağı olacă̆ını ifade etmiştir ${ }^{102}$.

Görüldüğü üzere Hasan Basrî Bey’deki Şûrâ-yı Devlet algısı ilginçtir. Halk idaresinin Mecliste tecelli ettiğini bu çerçevede artık Şûrâ-yı Devlete gerek olmadığını ifade etmektedir. Ondaki algı, Şûrâ-yı Devletin Millet Meclisinin alternatifi olarak görülmesidir. Oysaki parlamento olarak kabul edilemeyecek Şûrâ-yı Devlet, hiçbir zaman bir yasama organı özelliği kazanmamıştır ${ }^{103}$.

Tartışmaların devam ettiği bir sırada Hasan Basri Bey’in Şûrâ-yı Devleti oldukça sert bir şekilde eleştiren bu ifadeleri karşısında Şûrâ-yı Devletin savunucuları arasında yer alan Celâleddîn Arîf Bey: “'Basri Bey sorarım: Şûrâ-yı Devlet mukarreratının hepsini zat-ı âliniz tedkîk buyurdunuz mu? Ceffe'l-kalêm (rastgele) söz söylemek doğru değildir.” itirazında bulunduğu görülmektedir.

Hasan Basrî Bey ise cevaben; "Şûrâ-yı Devletin tarihçesini, Meclis-i Âli emrederse, sizin de istifade edeceğiniz bir surette arz ederim. Bilmediğim bir mesele hakkında bir şey söylemek mutadım (alışkanlığım) değildir.” şeklinde soruyu cevaplandırdıktan sonra yapılan görüşmelerin yeterli olduğuna kanaat getirilmiş ve lehe ya da aleyhe söz alma faslı son bulmuştur ${ }^{104}$.

Görüşmelerin ardından tam 12 (on iki adet) takrîr/önerge Riyâset-i Celîleye/ Meclis Başkanlığına takdîm edilmiştir. Önergelerin mahiyeti de pek tabiî olarak görüşmelerde yaşanan taban tabana zıtlığı yansitmakta idi ${ }^{105}$. Örneğin Yozgat Mebusu Feyyaz Âli Bey’in verdiği önergenin birinci maddesi: "Şûrâ-yı Devlet teşkilatı mülgadır” ve Erzurum Mebusu Hüseyin Avni Bey’in verdiği önergenin

102 Ayni yer, s. 425.

103 Şûrâ-yı Devletin neden bir yasama organı olarak ele alınamayacağına dair tafsilâtlı bir tahlîl ve tartışma için bk. Eraslan, age., s. 116-123; Onur Karahanoğulları, Türkiye'de İdari Targı Tarihi, Turhan Kitapevi, Ankara 2005, s. 150.

104 Ayni yer, s. 427.

105 Takrîrler/Önergeler için bk. TBMMZC, İçtima: 139, Celse 2, s. 427-431. 
üçüncü maddesi: "Şûrâ-yı Devlet mülga olup vezâif-i taalluku itibariyle Vekâletlere mevdûdur" şeklinde iken Bursa Mebusu Operatör Emin Bey, Kırşehir Mebusu Sadık Bey ve Aydın Mebusu Tahsin Bey, biri Mülkiye, diğeri ise Maliye ve Nâfia olmak üzere iki daireden oluşan yeni bir Şûrâ-yı Devlet modelini önermekte oldukları görülmektedir.

Türkiye'de Tanzimat sonrasinda taşrada kurulan Muhassıllık Meclisleri ve Vilâyet Meclisleri ile merkezde kurulan Meclis-i Vâlâ ve Meclis-i Âlî-i Tanzimatla ilk nüvesi oluşmaya başlayan idari yarg, dolayısı ile idari rejime geçiş süreci Şûrâ-yı Devletin kurulması ile daha da belirgin ve sistematik bir şekil almış ve ikili yargı yapısının temelleri atılmıştı. Musa Kâzım Bey verdiği önerge ile bu yapıdan vazgeçilmesini istemekte ve tekli yargı sistemi önerilmekte idi. Esasen bu uygulama 4 Şubat 1329/17 Şubat 1914 tarihli Me’mûrîn Muhâkemât-1 Hakkında Kanûn-1 Muvakkatın ${ }^{106} 1$. maddesi ile bir yönü ile hayata geçirilmekle birlikte daha sonra bundan vazgeçilmişti. Fransa'dan mülhem olan ve Cumhuriyet Türkiye'sinde tam anlamıyla oturacak olan idari rejim ve ikili yargı sistemi sürecinden geri dönüşe ilk TBMM'de de cevaz verilmemiş ve 1920 ve 1921 yıllarında yani Millî Mücadele Dönemi'nin devam ettiği süreçte Şûrâ-yı Devletin ilgasına yönelik teklifler ve gerekse yeniden teşkiline dair teklifler kabul görmemiştir.

İkinci celse 139 nolu içtimada nazar-1 mütâlaya (üzerinde etraflıca düşünmeye) alınan önerge Canik Mebusu Nafiz Beye ait olmuştur. Bu önerge, "Şûrâ-yı Devletin Vezâif-i Umûmiye-i Kanûniyesi Büyük Millet Meclisinden müntehap dokuz zattan mürekkep bir Heyete tevdiîne dair" kanun teklifidir. Ancak bu teklif de bahsi geçen görüşmeler sonrasında yasalaşmamıştır. Diğer dikkat çekici bir önerge de Cebelibereket Mebusu Rasim Bey tarafindan sunulmuştur. Bu önergede "Şûrâyı Devlet büyük vatanperver merhum Mithad Paşa tarafindan tesis edilmiştir. Bir luzûm-1 kat'iyeye binâen tesîs edilmiş olan bu müessesenin merhûm-1 müşârün-ileyhin namına hürmeten olsun ilga edilmemesi” teklifi yer almış ancak önerge dikkate alınmamıştır. Durum böyle olsa da önergede Mithat Paşa'ya yapılan vurgu dikkat çekicidir. (s. 431)

\section{Sorunu Çözmeye Yönelik Son Adımlar}

Şûrâ-yı Devlet üzerine oldukça derinlikli ve tafsilatlı tartışmalar 29.1.1337/1921 tarihinde 139. içtimada yapılmış ve bu Kurumun yeniden teşkîli yerine görevlerinin TBMM içinden seçilecek bir heyetlere bırakılması uygun görülmüştü. Uzlaşı-

106 Düstur, II. Tertip, Cilt 6, ss. 207-211. 
lan husus kanunlaşmadığından mezkûr Kurum üzerine yapılan tartışmalar Mecliste mütemadiyen devam etmekte idi. 7.4.1337(1921) tarihli Meclis Gündeminde Şûrâ-yı Devlet Lâyihası ve buna ilişkin Dâhiliye ve Adliye Encümeni Mazbataları yer bulmuştu ${ }^{107}$. Hasan Basri Bey; “...Memûrîn Muhâkemâtına Dâir bir Kanunun aylardan beri durduğunu, yüzlerce memurun açıkta süründüğü ${ }^{108 ” " ~ g e r e k c ̧ e s i ~}$ ile lâyihanın görüşülmesini istese de diğer gündeme öncelik verilmiş olup çoğunluk sağlanamadığı için de bu konu görüşülememiştir.

16.4.1337(1921) tarihli Meclis Gündeminde Şûrâ-yı Devlet Teşkîline Dair İki Adet Kanun Lâyihası ile Adliye ve Dâhiliye Encümenlerinin Müşterek Mazbatasının yer aldığı görülmektedir ${ }^{109}$. Meclis Dâhiliye Encümeninde Şûrâ-yı Devlet Lâyihası/Taslağı görüşülmeye başlamıştır. Taslak ile müstakil bir Şûrâ-yı Devlet değil, bu Kurumun görevlerinin Meclis-i Âlî (TBMM) tarafından seçilecek üyeler tarafindan yerine getirilmesi önerilmiştir. Bu öneriyi hükûmetin tasvip etmediğini dile getiren dönemin Adliye Vekîli ve Trabzon Mebusu Hafiz Mehmet Bey, “... Çünkü Şûrâ-yı Devlet bir Heyet-i İstişâredir, âdeta Şûrâ-yı Devlet Hükûmetin maiyyeti demektir. Meclis-i Âlî âzalarının böyle Hükûmet memûru ve Hükûmetin maiyetinde bulunan bir Heyet-i İstişâreye âza olması, Meclis-i Âli âzalarının haysiyetiyle kabil-i tevfîk (uygun) değildir. Meclis-i Âlî âzaları lâyüsel(sorumsuz) dir. Binâenaleyh Hükûmet bu nokta-i nazardan Şûrâ-yı Devlet âzalarının, Büyük Millet Meclisi âzaları meyanından intihâbına muhâliftiri ${ }^{10}$." tespit ve gerekçeleri ile karşı çımıştır. Adliye Vekîlinin gözünden Şûrâ-yı Devletin nasıl gözüktüğü ve algılandığını ortaya koymak açısından bu tespitler son derece önemlidir. Adliye Vekili, TBMM üyelerinin Şûrâ-yı Devlet üyeliği ile görevlendirilmesini bir tenzîl-i rütbe olarak görmektedir. Ayrıca Şûrâ-yı Devleti Hükümetin emrinde ve idarenin bir unsuru olarak gördüğünü ortaya koymaktadır. Yapılan tartısmalar böyle bir tutuma sadece Adliye Vekilinin değil önemli derecede mebusun da iştirak ettiğini göstermektedir.

Hasan Basri Bey Şûrâ-yı Devlet üzerine daha önce yapılan (29.1.1337/1921-139. İçima) tafsîlâtlı görüşmelere göndermede bulunarak o dönemde Canik Mebusu Nafiz Beyin verdiği önergenin Mecliste kabul edildiğini, "Binâenaleyh kabul edilen bu esâs dairesinde icrâ-yı hareket zaruridir ${ }^{111}$." diyerek yeniden Şûrâ-yı Devlet

107 TBMMZC, İçtima: 17.

108 TBMMZC, İçtima: 17, Gelse 2 (7.4.1337), s. 400.

109 TBMMZC, İçtima: 21.

110 TBMMZC, İçtima: 21, Celse 1 (16.4.1337), s. 8-9.

111 Aynı yer, s. 9. 
üzerine uzun uzadıya tartışma yapılmasının önüne geçmek istemiştir. Ancak önceden olduğu gibi lehe ve aleyhe pek çok konuşma söz konusu olmuştur. Trabzon Mebusu Ali Şükrü Bey'in yaklaşımı ise tamamen bütçe odaklı olmuş, bütçeye getireceği yük hesap edildiğinde Şûrâ-yı Devletin teşkîl edilmemesi gerektiğinin altını çizmiştir ${ }^{12}$. Yapılan görüşmeler sonucunda Dâhiliye Encümenince hazırlanmış ve Meclis Başkanlığına sunulmuş olan Lâyiha reddedilmiştir ${ }^{113}$.

2.7.1337/1921 tarihli TBMM Gündemine bakıldığında gündemin 7. maddesinin ikinci alt sırasında yer alan alt başlıkta "Şûrâ-yı Devlet Teşkîli hakkında (iki tane) Kanun lâyihası ve Adliye ve Dâhiliye Encümenleri Mazbataları" ibaresi göze çarpmaktadır ${ }^{114}$. Ertuğrul (Bugünkü Bilecik) Mebusu Mustafa Kemal (Güney), Riyâset-i Celîle’ye verdiği takrîr/önerge ile "pek çok memûrînin mağdur bir durumda bulunduğundan” bahisle Şûrâ-yı Devletin teşkîli hususunun müstacelen/ ivedi olarak görüşülmesini istemektedir ${ }^{115}$. Bu önergenin akabinde daha önceki görüşmelerde de olduğu üzere Şûrâ-yı Devlet lehine ve aleyhine birçok görüş ortaya konmuştur.

Yapılan tartışmalardan sonra önerge sahibi Ertuğrul Mebusu Mustafa Kemal (Güney) verdiği önergeyi değiştirmiş ve Meclis Başkanlığına “...Şûrâ-yı Devlet teşkîli hakkındaki Kanunun tanzîminden maksat, doğrudan doğruya memûrîn muhâkemâtına ait evrakın tedkîkinden ibaret bulunmasına nazaran iş bu teşkilâta (Encüme-i Tedkîk) unvanı verilmesi temini maksada kâfi olduğundan..." Şûrâ-yı Devletin yeniden oluşturulmasının odak noktasını memur yargılamalarına indirgemiş bu yönüyle de memur yargılamaları sürecinde görev yapacak yerin Şûrâ-yı Devlet adıyla değil Encümen-i Tedkîk olarak güncellenmesini talep etmiştir ${ }^{116}$. 2 Temmuz 1337/1921 tarihindeki görüşmelere "İsim Tartışmaları" damga vurmuştur. "Şûrâ-yı Millet", Şûrâ-yı Tahkîk" ve "Şûrâ-yı Tedkîk" gibi çeşitli isim önerileri ortaya atılmıştı ${ }^{117}$. Başka bir öneri ise Bolu Mebusu Tunalı Hilmi Bey'den gelmiştir. Kanunun adının: "Şûrâ-yı Devlet Mülkiye Dairesi Kanunu"18" olmasını teklif etmiştir. Ancak bu isim önerileri kabul görmediği gibi kanun lâyihası da bu tarihte çoğunluk ve uzlaşı sağlanamadığı için Meclisten geçmemiştir.

112 Ayni yer, s. 14.

113 Aynu yer, s. 16-17.

114 TBMMZC, İçima: 45. Celse 2 (2.7.1337), s. 105.

115 Aynı yer, s. 105.

116 TBMMZC, İçtima: 45, Celse 2 (2.7.1337), s. 112.

117 Ayni yer, s. 112-113.

118 Ayni yer, s. 113. 


\section{Görev ve Yetkilerin TBMM'ye Devri ve Şûrâ-yı Devletin Ortadan Kaldırılışı}

Şûrâ-yı Devlete verilen görevlerden bir kısmını yerine getirmek için bir merci kurulması zorunluluğu hissedilmiş ve Şûrâ-yı Devletin yeniden teşkili, dönüşümü ve ilgası üzerine TBMM'de yapılan yoğun tartışmalar, 4 Temmuz 1921 tarih ve 131 sayılı Şûrâ-yı Devletin Memûrîn Muhâkemâtına Müteaâllik Vezâifinin Sûret-i Ifâsı Hakkında Kanun ${ }^{119}$ ile bir süreliğine son bulmuştu. Toplam altı maddeden oluşan bu kanunun 1. maddesi ile 17 Şubat 1914 (4 Şubat 1329) tarihli Me'mûrîn Muhâkemât-1 Hakkında Kanûn-ı Muvakkatın ${ }^{120}$ dördüncü, altıncı, sekizinci, dokuzuncu, onuncu maddelerinde yazılı Şûrâ-yı Devlet Mülkiye Dairesine ait vezâif Büyük Millet Meclisi Heyet-i Umûmîyesince Meclis âzasından seçilen dokuz zattan teşekkül eden "Me'mûrîn Muhâkemât Encümeni” tarafindan, Şûrâ-yı Devlet Heyet-i Umûmûyesine ait vezâif için ise yine Meclisin Heyet-i Umumiyesince ayrıca seçilecek on beş zattan mürekkep "Me'mûrin Muhâkemâtı Heyeti"nce yerine getirileceği, encümen ve heyetin altı ayda bir yeniden, eski üyelerin ise tekrar seçilebileceği, Encümen ve Heyetin aldığı kararların Meclis onayına sunulmasına gerek bulunmadığı hükme bağlanmıştır. Adı geçen "Encümen"in "Muhâkemât Dairesi" yerine; "Heyet"in ise Muhâkemât Dairesi bidâyet kararlarının temyîzini görüşen "Heyet-i Umûmiye/Genel Kurul" yerine ihdâs edildiği anlaşlmaktadır. Düzenlemede durum bundan ibaret olmakla birlikte yapılan bir çalışmada "belirli bir süre ve konu ile sinırlı olan bu encümenlerin Meclis’in teşri, icrai ve adli yetkilerini sürekli ve süratli bir şekilde kullanmaya çalıştığını gösterdiği” iddia edilmiştir ${ }^{121}$. Oysaki bahsi geçen Encümenlerin kendisine verilen sinırlar dâhilinde hareket ettiği, TBMM'nin de teşrî (yasama) yetkisini bu kurullara devretmesinin kesinlikle söz konusu olmadığı, yine memur yargılaması dâhilinde idari yargı yetkisi kullanmanın ötesinde bu encümenlerin 131 sayılı Kanun düzenlemesi bağlamında bahsi geçen çalışmada yer aldığı şekliyle "Meclis kendi içinde bir adli teşkilat oluştururcasına" çalışmamış ve adı geçen encümen heyetlerince adli (yargi) yetkisi kullanmamıştır.

Osmanlı Devleti’nde Şûrâ-yı Devletin teşkîlinden itibaren Vilayet İdare Meclislerinde görülen memur yargılamalarına ilişkin kararlar bilindiği üzere Nizâmnâme-i Dâhilîsinin 3. maddesinin dördüncü fikrası gereği "Nizâm-1 iktizâsınca Şûrâ-yı

119 TBMMZC, İçtima: 46, Celse 2 (4.7.1337), s. 136. (Cerîde-i Resmîye, 11 Temmuz 1337, No:20)

120 Distur, II. Tertip, Cilt 6, ss. 207-211.

121 Açılamah Yönetim Zaman Dizini (1919-1928), G 1, s. 504. 
Devletin temyîz ve tasdîkine mevkûf olan me'mûrîn muhâkemesinin tedkîk ve hükmü ${ }^{122 " ” ~ d o g ̆ r u l t u s u n d a ~ S ̧ u ̂ r a ̂-y ı ~ D e v l e t ~ t a r a f i n d a n ~ i n c e l e n i p ~ k a r a r a ~ b a g ̆ l a n m a k t a ~ i d i . ~}$ 4 Temmuz 1921 tarih ve 131 sayılı Kanunla Şûrâ-yı Devletin memur yargılamalarına ilişkin yetkileri TBMM Üyelerinden seçilen heyetlere devredilince bu durum Vilayet İdare Meclislerinin aldığı kararlara ilişkin "tedkîk ve intâc/inceleme ve neticelendirme" merciinin boşlukta kalmasına ve bu durumun mağduriyetlere yol açmasından dolayı ${ }^{123}$ İdâre-i Umûmiye-i Vilâyât Kanununun ${ }^{124}$ Şûrâ-yı Devlete gönderme yapan 67. maddesinin son fikrası ile 68. maddesinde gösterilen mukarrerâtın, Mecliste daha önce teşekkül eden Encümene tevdi edilmesini teminen vilayetlerden gelen evrakın itiraz merciine ilişkin boşluğu gidermek için Bolu Mebusu Şükrü Bey tarafindan 12 Temmuz 1337 tarihinde, 131 sayılı Kanuna ek madde (madde-i müzeyyele) olarak bir kanun teklifi verilmiştir ${ }^{125}$. Diğger taraftan gerek İktisat Vekîli ve Saruhan Mebusu Mahmut Celal Bey ve gerekse Canik Mebusu Nafiz Bey bu görüşmeler esnasında işin başka bir yönüne de dikkat çekmişlerdir. Yapılan yasal düzenlemelere rağmen Şûrâ-yı Devletin yürürlükte bulunan yasası gereği kendisine verilen diğer görevleri yerine getirecek başka bir resmi mercinin bulunmamasından bahisle bazı mağduriyetlerin yaşanacağını bu çerçevede bu görevler için de kanuni bir merciinin tayin edilmesi gerektiğini ifade etmişlerdir ${ }^{126}$. Yapılan görüşmelerin ardından Meclis Dâhiliye Encümeni tarafindan hazırlanan mazbatada ${ }^{127}$ Bolu Mebusu Şükrü Bey'in teklifine İdâre-i Umûmiye-i Vilâyât Kanununun 135. maddesi de eklenmiştir. Daha sonra yapılan görüşmelerde ise kanun teklifine 146. maddenin de eklenmesi ile mezkûr kanun teklifi 31 Aralık 1921 tarih (31 Kanûn-ı Evvel 1337) ve 177 sayı ile yasalaşmışır.

4 Temmuz 1921 tarih ve 131 sayılı Kanun ile Şûrâ-yı Devlet tartışmalarının büyük oranda kapandığı görülmekle birlikte İktisat Vekîli ve Saruhan Mebusu Mahmut Celal Bey ve Canik Mebusu Nafiz Bey’in yukarıda değinilen beyanatlarında

122 BOA, İ. DUİT, 58/48-2 ve Diistûr, 1. Tertip, 1. Cilt, Matbaa-i Âmire, 1289, s. 707-718.

123 İktisat Vekîli ve Saruhan Mebusu Mahmut Celal Bey, bu minvâlde bir konuşma yapmıştır. Bk. TBMMZC, İçtima: 132, Gelse 2 (22.12.1337), s. 206-207.

124 Düstur, II. Tertip, Cilt 5, s. 186-216.

125 TBMMZC, İçtima: 132, Gelse 2 (22.12.1337), s. 206.

126 Ayn yer, s. 206-208. Canik Mebusu Nafiz Bey bu düşüncesini “ ... henüz ref ve tağyir edilmemiş tebdil ve tahvil edilmemiş olan kavânîn-i mevcûdeye nazaran Şûrâ-yı Devlete müteallik vezâif bugün muallaktır.” şeklinde ifade etmiştir. Bk. aynı yer, s. 208.

127 Mazbata 26 Teşrîn-i Evvel 1337 (26 Ekim 1921) tarihlidir. Bk. Aynı yer, s. 206. 
da görüldüğü üzere netice alınamasa da Şûrâ-yı Devlet tartışmaları zaman zaman devam etmiştir. Bu noktadaki en dikkat çekici örneklerden biri de Bursa Mebusu Operatör Emin Bey'in Meclis içerisinden seçilen Encümen ve Heyet üyelerinin seçiminde yaşanan zaman kaybı ve işlerin yoğunluğu dolayısı ile daha önce Şûrâyı Devlete ait olan görevlerin yürütülmesinde aksamalar yaşandığından bahisle "Muvakkat Bir Şûrâ-yı Devlet Teşkîline Dair" bir kanun teklifi vermesidir. Bu teklifin Meclisçe 12 Ekim 1922'de gündeme alındığını görmekteyiz ${ }^{128}$. Emin Bey kanun teklifinde; daha önce Sivas'ta teşkîl edilen muvakkat Temyiz Heyetine benzer şekilde Konya'da Maliye, İktisat ve Muhâkemât Dairelerinden oluşan muvakkat bir Şûrâ-yı Devletin teşkîl edilmesinin uygun olacağını önerse de Meclis Genel Kurulunca; maliye hazinesinin teklif olunan tę̧kilata müsait olmadiğı ve seçilmiş mevcut üyelerle yükümlülüklerin yerine getirilmesinin mümkün olduğundan bahisle bu teklif, şâyan-1 müzâkere görülmemiş ve reddedilmiştir.

Şûrâ-yı Devletin TBMM tarafindan teşkil edilmesine yönelik son başarısız deneme olan Emin Beyin kanun teklifinin kabul edilmediği aynı ayın sonunda TBMM tarafindan 30 Ekim 1922 (30 Teşrîn-i Evvel 1338) yılında "Osmanlı İmparatorluğunun münkariz olduğuna ve Büyük Millet Meclisi Hükûmeti teşekkül ettiğine ve Yeni Türkiye Hükûmetinin Osmanlı İmparatorluğu yerine kaim olduğuna" karar ${ }^{129}$ verilmiştir. 1 Kasım 1922 yılında ise TBMM tarafından "Türkiye Büyük Millet Meclisinin Hukûk-ı Hâkimiyet ve Hükümrânının Mümessil-i Hakîkisi Olduğuna Dâir Karar ${ }^{130 "}$ ile Saltanat kaldırılmıştır. Bu gelişmeler üzerine Osmanlı Devletinin son Sadrâzamı Ahmet Tevfik Paşa'nın ${ }^{131}$ başında olduğu son İstanbul Hükûmeti 4 Teşrîn-i Sânî 1338/4 Kasım 1922'de istifa etmiştir. Bu istifa ile birlikte Şûrâ-yı Devletin Osmanlı Devleti’ndeki hukuki ve fiili sergüzeşti sona ermiştir.

\section{Sonuç ve Değerlendirme}

Şûrâ-yı Devlet Türkiye'de idari rejime geçişin simgesi olmuş ve Kıta Avrupa'sı ülkelerindekine benzer şekilde ikili yargı sisteminin temellerini atmıştır. İlham kaynağı Fransa'daki Conseil d'Etat/Konsey Deta 1872'de tutuk adaletten bağımsız adalete geçmiştir. Bu bağlamda II. Meşrutiyet ve Millî Mücadele Dönemi’nde

128 TBMMZC, İçtima: 118, Celse 1 (12.10.1338)

129 TBMM Kararı No: 307 (30 Teşrîn-i Evvel 1338), Düstur, III. Tertip, Cilt 3.

130 TBMM Kararı No: 308 (1 Teşrîn-i Sânî, 1338), Düstur, III. Tertip, Cilt 3.

131 Ayrıntılı bilgi için bk. Nurten Çetin, Son Sadrâzam Ahmet Tevfik Paşa, ATAM Yay., Ankara 2015. 
Şûrâ-yı Devlet için de benzer arayışların somut adımlar atılmak suretiyle söz konusu olduğu görülmüştür. Ancak her iki dönem de hazırlanan lâyihaların akamete uğramasıyla bu seviyeye ulaşılamamıştır. Her ne kadar Şûrâ-yı Devlet hukuken idarenin içinde yer alsa da fertler ile hükûmet arasındaki anlaşmazlıkları çözüme bağlama ve memur yargılamaları noktasında idarenin üstünde yer almıştır. Kararların tenfîz kabiliyeti hukuken yeterince teminat altına alınmamış olsa da nezaretlerin özellikle II. Meşrutiyetten önceki dönemde Şûrâ-yı Devlet kararlarını büyük ölçüde dikkate aldığı anlaşılmaktadır.

II. Meşrutiyet ve Millî Mücadele Dönemi Şûrâ-yı Devlet hakkında yoğun tartışmalara sahne olduğundan bu Kurumun yapisal değişim ve dönüşümüne imkân tanıyan hukuki düzenlemeler sıkça bu dönemlerde de söz konusu olmuştur. Kurulduğu 1868'den ortadan kaldırıldığı 1922 yılına kadar farklı tartışmaların odağında yer alan Şûrâ-yı Devlet zaman zaman yıpransa da aslında süreç içerisinde yaşanan gelişmeler kurumsallaşmasına da ciddi katkı sağlamıştır. Osmanlıdan Cumhuriyet Türkiye'sine tevarüs eden Kurumlardan hiçbiri kurulduğu ilk yıllarda TBMM'nin gündemini Şûrâ-yı Devlet kadar meşgul etmemiş hatta onun kadar sert tartışmalara yol açmamıştır. Şûrâ-yı Devletin çoğunlukla politik tesir altında geçen tarihi bu Kuruma olan menfî direnç noktalarını beslemiştir. Bununla birlikte Şûrâ-yı Devlet görev, yetki ve sorumluluklarını yerine getirirken oldukça önemli bir hizmet alanına karşılık gelmiş ve kendi görev sahasında ciddi anlamda uzmanlaşmıştır. Bu husus kendisine duyulan ihtiyacı canlı tutmuştur.

Bu çalışmanın ortaya koyduğu üzere Şûrâ-yı Devlet işgal yıllarının yaşandığı Mütareke Dönemi de dâhil olmak üzere İstanbul'da çalışmalarına devam etmiştir. Esasen yarım asrı aşan tecrübe ve birikimi ile Şûrâ-yı Devlet devletin merkezi yönetimi için alternatifi olmayan bir müessesedir. Nitekim TBMM Zabit Cerideleri ortaya koymaktadır ki, Ankara Hükûmetinin de meseleye bakışı bu yöndedir. TBMM'de Heyet-i Vekile Üyeleri tümüyle bir İtisas Kurumu olan Şûrâ-yı Devletin yeniden teşkil edilmesini savunurken bazı mebusların şiddetle karşı çıktıkları görülür. Buradaki ayrışma siyasi ya da ideolojik değil, icrâi sorumluluk taşıyanların Şûrâ-yı Devletin uygulamada neye karşılık geldiğini diğer mebuslara göre daha iyi görmesinden kaynaklanır. Devlet aygıtı içerisinde bazı eksikliklerine rağmen Şûrâ-yı Devletin nasıl bir boşluğu doldurduğu, hükûmet üyeleri tarafindan daha dikkatli bir şekilde takdir edilmiştir. İlk TBMM'deki Şûrâ-yı Devlet ile ilgili yapılan sert ve taban tabana zıt tartışmaların ortaya koyduğu Şûrâ-yı Devlet algısı, hiç kuşkusuz Kurumun 54 yıllık sergüzeştinin yansımasıdır. Tartışmalarda da görül- 
düğü üzere Dâhiliye, Adliye ve Nâfia Vekîlleri, Şûrâ-yı Devlete duyulan ihtiyacın gerekçelerini gayet derinlikli analizlerle ortaya koymuştur. Altı çizilen ihtiyaç sıralamasında "Memûrun Muhâkemâtı" ile ilgili konu ilk sırada yer almıştır.

TBMM Zabıt Cerideleri (1920-1922) bir bütün olarak ele alındığında özellikle Yeni Türk Hükûmetinin Şûrâ-yı Devleti yeniden kurma noktasındaki inancının tam olduğu görülür. Nitekim bu inanç neticesiyledir ki Cumhuriyet Türkiye'sinin ilk anayasası olan 1924 Anayasasının 51. maddesiyle Şûrâ-yı Devlet anayasal konumunu korumuş ve yeniden kurulması karara bağlanmıştır.

Millî Mücadele Dönemi'nde TBMM'de Şûrâ-yı Devletin yeniden teşkîl edilmesine sıcak bakılmamasının en önemli odak noktalarından birini bütçe sorunu oluşturmaktadır ki, dönemin koşullarında bu Kurumun yeniden ihdası ile ilgili pek çok yaklaşımda itiraz kaynağını bu sorun oluşturmaktadır. Nitekim Heyet-i Vekîle'nin TBMM'ye ilk sunduğu 16.9.1336/1920 tarihli lâyihaya ilişkin Meclis Dâhiliye Encümeni tarafindan hazırlanan 28 Ekim 1920 (28 Teşrîn-i Evve1336) tarihli mazbata tutanağında; Meclisin devamlı toplanması sebebiyle Şûrâ-yı Devletin muhtelif görevlerini üstlendiği ifade edilmiş ve Şûrâ-yı Devletin yeniden inşasına yönelik müspet teklifler "...İcâbât-ı hâl ve zaman itibariyle tasarrufat-ı maliyeye şiddetle muhtaç bulunduğumuz mücadele hayatımızda yeni yeni teşkilâtlarla bütçenin tezyîdinin asla doğru olmadığı..." gerekçesi ile ilave mali yüklerden bahisle reddedilmişti. Mali külfeti dikkate alan bu tutum dönemin koşullarında anlaşlır bir durumdur. Devletin içinde bulunduğu siyasi ve ekonomik şartlar bu türden yaklaşımlara kapı aralamaktaydı. Fakat bu yaklaşım üzerinde de hemfikir olma söz konusu değildir. Ancak Meclisin devamlı toplanması sebebiyle Şûrâ-yı Devlete gerek görülmediğinin vurgulanması ise bu Kurumun dönemin koşullarında nasıl algılandığını gösteren başka bir bakış açısını daha ortaya koymaktadır. Şöyle ki, Şûrâ-yı Devlet, 1876 Anayasası ile parlamento açılmadan önceki son geniş katılımlı meclisti. Bir parlamento olmasa da imparatorluğun tüm unsurlarının merkezde temsiline imkân verilmesi amaçlanmıştı. Millî Mücadele Dönemi’nde de Şûrâ-yı Devleti parlamento gibi gören bir anlayışın bazı mebuslarda devam ettiği görülmektedir.

Bu çalışmada ortaya konan diğer bir tespit; adli yargının temyiz mercii olan "Mahkeme-i Temyîz" ile idari yargının temyiz mercii olan Şûrâ-yı Devlete TBMM'nin yaklaşım biçiminde kendisini ortaya koymaktadır. Şûrâ-yı Devlet için söz konusu olan ve sonuç alınamayan tartışmaların aksine TBMM'nin açılmasının üzerinden daha iki ay geçmeden ivedilikle kanun çıarılmış ve Sivas'ta "Heyet-i Temyîz" 
kurularak Anadolu'daki adli yargı mercilerinin İstanbul ile irtibatının kesilmesi tercih edilmiştir. Bu, TBMM Hükûmetinin adli yargı açısından Anadolu’yu kontrol etmek istemesi ve hâkimiyetini pekiştirmesi ile açıklanabilecek bir durumdur.

Bu çalışmanın ortaya koyduğu diğer gerçeklik ise şudur: 1920-1922 tarihleri arasında hizmet veren tek Şûrâ-yı Devlet vardır ve o da İstanbul Şûrâ-yı Devletidir. TBMM'de her ne kadar tartş̧ılsa da Millî Mücadele Dönemi'nde yeni bir Şûrâ-yı Devlet teşkilatı Anadolu'da kurulamamıştır. Fonksiyonlarının bir kısmı ise TBMM'de kurulan bazı heyetlere devredilmiştir. Ancak bahsi geçen Kuruma duyulan ihtiyaç kısa sürede kendini ortaya koymuş olup yeniden kurulması sorunu Cumhuriyet Türkiye'sinin ilk anayasası ile çözüme kavuşmuştur.

Netice olarak; 20. yüzylın politika geliştiricilerine mühim ve anlamlı bir miras olarak intikal etmiş olan Şûrâ-yı Devlet, 1922 ile 1924 arası dönemde kesintiye uğrasa da bir "İhtisas Kurumu" olarak yeni kurulan üniter Türkiye Cumhuriyeti’nin de vazgeçilmez kurumları arasında yerini almış olup varlığını bugün Danıştay adıyla devam ettirmektedir. 


\section{KAYNAKLAR}

\section{Arşiv Kaynakları}

Cumhurbaşkanlığı Devlet Arşivleri Başkanlığı Başbakanlık Osmanlı Arşivi (BOA) BOA, İ.DUIT, 58/51-2.

BOA, İ. DUIT, 58/48-2.

BOA, HH, 16425

BEO, 4568/342528_2

BOA, İ.DUIT. 58/23-1

BOA, ŞD, $3197 / 32$

BOA, ŞD, 2813/10-2

BOA, DUİT, 8/51

İâde-i Seniyye, Düstûr, II. Tertip, I. Cilt, s. 71-72

\section{Kanunlar/Nizâmnâmeler ve TBMM Kararları}

Şûrâ-yı Devlet Nizâmnâme-i Esâsîsi, Düstûr, 1. Tertip, 1. Cilt, Matbaa-i Âmire, 1289, s. 703-706.

Şûrâ-yı Devlet Nizâmnâme-i Dâhilîsi, Düstûr, 1. Tertip, 1. Cilt, Matbaa-i Âmire, 1289, s. 707-718.

1909 Anayasa Değişikliği, Düstur, II. Tertip, Cilt 1, s. 638-644.

1325 tarihli Muvâzene-i Umûmîyye Kanûnu, (1 Ağustos 1325/14 Ağustos 1909), Düstur, II. Tertip, Cilt: 1, ss. 438-602.

1325 Tarihli Tensîkât Kanûnu (17 Haziran 1325/30 Haziran 1909), Düstur, II. Tertip, Cilt 1, ss. 326-333.

1336 tarihli Muvâzene-i Umûmiye Kanûnu, (Cerîde-i Resmîye ile Neşir ve İlanı: 25 Nisan 1337/25 Nisan 1921, No:12)

1329 tarihli Me'mûrîn Muhâkemât-1 Hakkında Kanûn-1 Muvakkat, (4 Şubat 1329/17 Şubat 1914), Düstur, II. Tertip, Cilt 6, s. 207-211.

1329 tarihli İdâre-i Umûmiye-i Vilâyât Kanûnu,(13 Mart 1329/26 Mart 1913), Düstur, II. Tertip, Cilt 5, s. 186-216. 
4483 sayılı "Memurlar ve Diğer Kamu Görevlilerinin Yargılanması Hakkında Kanun” ile yürürlükten kaldırılmıştır. 4483 sayılı Kanun günümüzde de yürürlüktedir. Bk. Düstur, 5. Tertip, Cilt: 39.

Muvakkat Temyiz Heyeti Teşkîline Dair Kanun, Ceride-i Resmiye ile Neşir ve ilanı, 7 Şubat 1337/1921, No: 1.

TBMM Kararı No: 307 (30 Teşrîn-i Evvel 1338), Düstur, III. Tertip, Gilt 3.

TBMM Kararı No: 308 (1 Teşrîn-i Sânî, 1338), Düstur, III. Tertip, Cilt 3.

\section{Zabit Cerideleri}

Meclis-i Mebûsan Zabıt Ceridesi, 61. İn'ikat, Celse 1, 3 Mart 1334, s. 63-632.

TBMMZC, İçtima: 17, Celse 2 (7.4.1337)

TBMMZC, İçtima: 18, Gelse 1 (19.5.1336)

TBMMZC, İçtima: 21, Celse 1 (16.4.1337)

TBMMZC, İçtima: 23, Celse 1.(3.6.1336)

TBMM Zabıt Ceridesi, İçtimâ: 25, Celse: 7, (7.6.1336. tarihli Kanunun Ceride-i Resmîye ile Neşir ve İlânı: 14 Şubat 1337-No:2)

TBMMZC, İçtima: 45, Gelse 2 (2.7.1337. Celse 2 sonunda yer alan Ek S. Sayısı: 3) TBMMZC, İçtima: 46, Celse 2 (4.7.1337 tarihli ve 131 sayılı Kanun/ Cerîde-i Resmîye'de yayımlanması 11 Temmuz 1337, No:20)

TBMMZC, İçtima: 132, Celse 2 (22.12.1337),

TBMMZC, İçtima: 139, Gelse 1 (29.1.1337).

TBMM Zabıt Ceridesi, (İçtima:158, Celse 2, 27.2.1337)

TBMMZC, İçtima: 118, Celse 1 (12.10.1338)

Gazeteler (1919-1922)

İkdâm

Irâde-i Milliye

Hâkimiyet-i Milliye 


\section{Araştırma ve İnceleme Eserler}

Abdurrahman Șeref Efendi, Son Vak'anüvis Abdurrahman Şeref Efendi Tarihi, "II. Meșrutiyet Olaylar", (Hazırlayan: Bayram Kodaman-Mehmet Ali Ünal), TTK Yay., Ankara 1996.

Açklamalı Yönetim Zaman Dizini (1919-1928), C 1, (Editör Nuray E. Keskin), Ankara Üniversitesi Siyasal Bilgiler Fakültesi Yayını, No: 604, Ankara, 2012

Ahmet Cevdet Paşa, Tezâkir 40-Tetimme, (Yay. G. Baysun), 3. baskı, TTK Yay., Ankara, 1991.

Ahmet Lûtfi Efendi, Vak'a-nüvis Ahmet Lûtfi Efendi Tarihi, (Yay. Münir Aktepe) C XII, TTK Yay., Ankara 1989.

Akın, Rıdvan, TBMM Devleti (1920-1923), İletişim Yay., İstanbul 2001.

Akın, Rıdvan, "TBMM'nin İlk Bütçe Yasası: 1336 Muvazene-i Umumiye Kanunu", İstanbul Üniversitesi Atatürk İlkeleri ve İnkalap Tarihi Enstitüsü Dergisi, S. 2, (2002), s. $1-40$.

Akşin, Sina, İstanbul Hükümetleri ve Milli Mücadele, C I-II, Türkiye İş Bankası Yayınları, Ankara 1998.

Armaoğlu, Fahir, "Tarihi Perspektif İçinde Misâk-1 Millı̂’nin Değerlendirilmesi”, Misâk-ı Millî ve Türk Dış Politikasında Musul, Atatürk Araş̧ırma Merkezi, Ankara 2012, s. 5-15.

Atatürk, Mustafa Kemal, Nutuk (1919-1927), 4. Baskı, Atatürk Araştırma Merkezi Yay., Ankara 1997.

Biren, Mehmet Tevfik, II. Abdïlhamid, II. Meşrutiyet ve Mütareke Devri Annlan 2, (Yay1na Hazırlayan: F. Rezan Hürmen), Arma Yay., İstanbul 1993.

Çetin, Nurten, Son Sadrâzam Ahmet Tevfik Paşa, ATAM Yay., Ankara, 2015.

Demirel, Ahmet, Birinci Meclis'te Muhalefet (İkinci Grup), İletişim Yay., İstanbul, 1994.

Demirel, Fatmagül, https://ataturkansiklopedisi.gov.tr/bilgi/Adliye_Vekâleti (erişim tarihi 15/12/2020)

Göreli, İsmail Hakkı, Devlet Şûrası (Şûrayı Devlet-Danıştay), Yeni Matbaa, Ankara 1953.

Gözübüyük, A. Şeref - Kili, Suna, Türk Anayasa Metinleri, Türkiye İş Bankası Yay., Ankara 1985. 
Eraslan, Zeki, Şûrâ-yı Devletten Danı̧taya: Yapısal ve Fonksiyonel Dönüşüm (1868-1922), Türk Tarih Kurumu Yay., Ankara 2018.

Eraslan, Zeki, Zeki, "Şûrâ-yı Devleti Hazırlayan Durum ve Şartlar", 150. Filında Şûrâ-yı Devletten Danıştaya Uluslararası Sempozyumu, 24-25 Ekim 2018, Danıştay Başkanlığı Yayını No:103, Ankara 2019, s. 38-66.

Findley,,Carter V., Ottoman Civil Officialdom (a social history), Princeton University Press, New Jersey 1989.

Findley, Carter V., Osmanl İmparatorluğu’nda Bürokratik Reform (çev. Ercan Ertürk), Tarih Vakfi Yurt Yay., İstanbul 2014.

JEZE, Gaston "Collaboration du Conseil d'Etat, et la doktirine dans l'élaboration dudroit administratif français", Livre jubilaire du Conseil d'Etat, 1952.

Karahanoğulları, Onur, Türkive’de İdari Yargı Tarihi, Turhan Kitapevi, Ankara 2005.

Menteşe, Halil, Osmanl Mebusan Meclisi Reisi Halil Menteşe’nin Anılan, (haz. İsmail Arar), Hürriyet Vakfi Yayınları, İstanbul 1986.

Muharrerât-ı Nâdire, Cild-i Sânî, s. 50-53. www.archive.org/stream/ (Collection: Ohio State University Library, publication date 1289/1872)

Shaw, Stanford J., "Th e Central Legislative Councils in the Nineteenth Century Ottoman Reform Movement before 1876", International fournal of Middle East Studies, Cambridge University Press, Vol. 1/No. 1 (Jan., 1970), pp. 51-84.

Oliver Dutheillet, Lamothe, "Fransız Danıştay'ı" (Le Conseil d'Etat), (çev. Hasan Basri Gültekin), Dansstay Dergisi, S. 50-51, Ankara, 1983, s. 3-21.

Onar, Sıdık Sami, İdare Hukukunun Umumî Esaslan, G 1, (2. Baskı), İsmail Akgün Matbaası, İstanbul 1960.

Saruhan, Zeki, Kurtuluş Savaşı Günlü̈̆̈̈, IV, TTK Basımevi, Ankara 1996,

Tural, Erkan, Son Dönem Osmanl Bürokrasisi: II. Meşrutiyet Dönemi’nde Bürokratlar, Ittihatçlar ve Parlamenterler, TODAIE Yay., Ankara 2009

Yayla, Yıldızhan, "Conseil d'Etat (Yapısı, İşlevi ve Yaklaşımı Üstüne)" İdare Hukuku ve İlimleri Dergisi, G 1/S. 1, İstanbul 1980, s. 79-86.

Yılmaz, Ejder, Hukuk Sözlüğü, 3. Baskı, Yetkin Yay., Ankara 2005. 
